\title{
Evaluation of the pathways of tropospheric nitrophenol formation from benzene and phenol using a multiphase model
}

\author{
M. A. J. Harrison ${ }^{1, *}$, M. R. Heal ${ }^{1}$, and J. N. Cape $^{2}$ \\ ${ }^{1}$ School of Chemistry, University of Edinburgh, West Mains Road, Edinburgh EH9 3JJ, UK \\ ${ }^{2}$ Edinburgh Research Station, Centre for Ecology \& Hydrology, Bush Estate, Penicuik, Midlothian, EH26 0QB, UK \\ * current address: Hadley Centre, Met Office, FitzRoy Road, Exeter, EX1 3PB, UK
}

Received: 23 December 2004 - Published in Atmos. Chem. Phys. Discuss.: 1 March 2005

Revised: 27 May 2005 - Accepted: 15 June 2005 - Published: 8 July 2005

\begin{abstract}
Phenols are a major class of volatile organic compounds (VOC) whose reaction within, and partitioning between, the gas and liquid phases affects their lifetime within the atmosphere, the local oxidising capacity, and the extent of production of nitrophenols, which are toxic chemicals. In this work, a zero-dimension box model was constructed to quantify the relative importance of different nitration pathways, and partitioning into the liquid phase, of mono-aromatic compounds in order to help elucidate the formation pathways of 2- and 4-nitrophenol in the troposphere. The liquid phase contributed significantly to the production of nitrophenols for liquid water content $\left(L_{c}\right)$ values exceeding $3 \times 10^{-9}$, and for a range of assumed liquid droplet diameter, even though the resultant equilibrium partitioning to the liquid phase was much lower. For example, in a "typical" model scenario, with $L_{c}=3 \times 10^{-7}, 58 \%$ of nitrophenol production occurred in the liquid phase but only $2 \%$ of nitrophenol remained there, i.e. a significant proportion of nitrophenol observed in the gas phase may actually be produced via the liquid phase. The importance of the liquid phase was enhanced at lower temperatures, by a factor $\sim 1.5-2$ at $278 \mathrm{~K}$ c.f. $298 \mathrm{~K}$. The model showed that nitrophenol production was particularly sensitive to the values of the rate coefficients for the liquid phase reactions between phenol and $\mathrm{OH}$ or $\mathrm{NO}_{3}$ reactions, but insensitive to the rate coefficient for the reaction between benzene and $\mathrm{OH}$, thus identifying where further experimental data are required.
\end{abstract}

\section{Introduction}

Nitrophenols were first reported in the environment, in rainwater, by Nojima et al. (1975). Investigation of the potential sources of nitrophenols was stimulated by the suggestion that toxicity arising from the deposition of nitrophenols

Correspondence to: M. R. Heal

(m.heal@ed.ac.uk) in rain could be one factor contributing to observed forest decline (Rippen et al., 1987; Natangelo et al., 1999). Subsequent analyses of samples of cloudwater, rainwater and snow have shown concentrations of nitrophenols to be significantly higher than would be expected from their direct emission (e.g. Levsen et al., 1990; Richartz et al., 1990; Tremp et al., 1993; Lüttke et al., 1997; Lüttke et al., 1999). Attention has therefore focused on the photochemical production of nitrophenols by reaction of mono-aromatics with $\mathrm{OH}$ radicals and $\mathrm{NO}_{\mathrm{x}}$ present in the atmosphere (Harrison et al., 2005). These reactions can occur in the liquid or gas phases, or a combination of both. While pathways of gas-phase oxidation of benzene and alkylsubstituted benzenes have been extensively studied (Atkinson et al., 1992; Grosjean, 1991; Klotz et al., 1998; Knispel et al., 1990; Lay et al., 1996), the fate of these aromatics with respect to the aqueous phase is less well characterised.

Clouds are the most abundant form of condensed water in the troposphere covering around $60 \%$ of the earth at any one time. A moderately dense cloud has a volumetric liquid water content of only about $3 \times 10^{-7}$ (Herterich and Herrmann, 1990; Molina et al., 1996), but despite the relatively sparse amounts of liquid water present in the atmosphere, condensed phase reactions play a surprisingly large role in atmospheric chemistry (Molina et al., 1996).

The most abundant aromatic species in the atmosphere, such as toluene, xylene and benzene, have very low Henry's Law coefficients (expressed as a liquid to gas ratio) and consequently will not partition into the aqueous phase to any significant extent. This does not make the aqueous phase irrelevant, for two important reasons: first, the Henry's Law coefficient describes an equilibrium process but if liquid phase reaction is fast then the liquid phase may still act as a competitive reaction channel; secondly, the more polar phenolic and nitrophenolic products of mono-aromatic hydrocarbon oxidation are likely to have significantly higher solubility in atmospheric water (Harrison et al., 2002).

(C) 2005 Author(s). This work is licensed under a Creative Commons License. 
In this work a zero-dimensional box model was constructed to describe the essential features of the monoaromatic nitration multiphase chemistry of the troposphere. The model was applied to identify the relative impact of different nitration pathways of mono-aromatics in the troposphere. It included the partitioning of 21 species and focused on the conversions of benzene to phenol to nitrophenols, in both the gas and liquid phases, and their phase partitioning.

\section{Description of the multiphase model}

The zero-dimensional model was coded using the FACSIMILE software which is designed specifically to solve complex chemical mechanisms (FACSIMILE, 2001). The model incorporated emission, deposition, gas and liquid phase reactions and phase transfer. The kinetic, thermodynamic and initial-value data used in the model are listed in Tables A1A19 of the Appendix, with brief descriptions given below.

\subsection{Gas and liquid phase species and initial concentrations}

Parameters describing the gas phase concentrations of species (Table A1) were taken from Herrmann et al. (1999, 2000) unless specified otherwise; time-dependent species were initialised with the values given in Table A2. All liquid phase species included in the mechanism (Table A3) were time-dependant, except for liquid water concentration $\mathrm{H}_{2} \mathrm{OL}$, and were initialised with the values of Herrmann et al. (1999, 2000) unless specified otherwise.

\subsection{Emissions}

Source emission rates of certain species into the box (Table A4) were chosen such that the model would adequately simulate a typical polluted troposphere. The emission rates for benzene and NO were taken from the Chemical Mechanism Development (CMD) protocol as reported by Poppe et al. (2001). The emission of phenol was set at $1.5 \%$ the emission of benzene in accordance with data from the UK National Atmospheric Emissions Inventory (NAEI, 2002).

\subsection{Dry deposition}

The dry deposition velocities incorporated into the model are listed in Table A5. The deposition rate depends upon the value assigned to the depth of the boundary layer. In this model, an average depth of $1000 \mathrm{~m}$ was used. Since the dry deposition of $\mathrm{O}_{3}$ and $\mathrm{NO}_{2}$ are strongly linked to stomatal uptake, which in turn is related to the light intensity, this diurnal behaviour was incorporated by coding deposition velocity proportional to $J\left(\mathrm{NO}_{2}\right)$.

\subsection{Gas phase reactions}

The latest IUPAC kinetic data were used to describe inorganic gas phase reactions (Tables A6 and A7) with data from the latest Master Chemical Mechanism (as first described by Saunders et al., 1997) used for methane and aromatic gas phase reactions (Tables A8 to A9). Temperature dependent rate coefficients were explicitly coded using the appropriate Arrhenius expression data. Termolecular reaction rate coefficients were calculated from the parameters $k_{0}, k_{\infty}$ and $F_{c}$ via the Troë approximation (Troe, 1983; Gilbert et al., 1983),

$k=\frac{k_{0} k_{\infty} F}{k_{0}+k_{\infty}}$

where $F$ is defined by,

$$
\log F=\frac{\log F_{c}}{1+\left(\log \left(\frac{k_{0}}{k_{\infty}}\right)\right)^{2}}
$$

\subsection{Photolysis coefficients}

Table A10 lists the gas phase photolysis reactions included in the model. The diurnal solar zenith angle $\chi$ was parameterised as described by Spencer (1971). "Clean" chemistry photolysis rate coefficients were parameterised in terms of $\chi$ using the CMD data of Poppe et al. (2001),

$J=A \exp \left(B\left(1-\frac{1}{\cos (C \chi)}\right)\right)$

whilst photolysis rate coefficients in gas phase methane oxidation were parameterised according to the MCM (Saunders et al., 1997),

$J=A(\cos \chi)^{B} \exp (C \sec \chi)$

( $A, B$ and $C$ are constants in each case).

\subsection{Gas-liquid phase transfer}

Clouds were modelled assuming monodisperse droplets of diameter, $d=1 \times 10^{-5} \mathrm{~m}$. The "base scenario" cloud liquid volume fraction, $L_{c}$, was $3 \times 10^{-7}$. These values are in line with those used in other multiphase models (Herrmann et al., 2000; Lelieveld and Crutzen, 1990; Molina et al., 1996; Poppe et al., 2001) and are also in agreement with measured cloud data from Great Dun Fell in the UK (personal communication J.N. Cape). However, given that the liquid water content of the atmosphere can vary widely (Voisin et al., 2000 ) the model was run for $L_{c}$ values in the range $3 \times 10^{-9}$ to $3 \times 10^{-6}$. Since different droplet diameters are expected at either end of this $L_{c}$ range, the model was also run with the assumption of water content distributed in droplets of diameter $1 \times 10^{-6} \mathrm{~m}$ or $1 \times 10^{-4} \mathrm{~m}$. Clearly not all $L_{c}$ and $d$ combinations are entirely physically realistic in the atmosphere and this is discussed later.

Molecular phase transfer was treated using the approach of Schwartz (1986) in which the transfer rates from gas to liquid, and liquid to gas, are described by $\frac{1}{4} \bar{c} A_{c} \Gamma_{\text {overall }}$ and $\frac{\bar{c} A_{c} \Gamma_{\text {overall }}}{4 L_{c} H R T}$, respectively, where $\bar{c}=\sqrt{\frac{8 R T}{\pi M}}$ is the mean molecular speed of the gas ( $M$ is the molar mass), $R$ is the molar 
gas constant, $T$ is the temperature, $A_{c}=\frac{6 L_{c}}{d}$ is the specific surface area of the liquid phase, $H$ is the Henry's Law coefficient, and $\Gamma_{\text {overall }}$ is the overall uptake coefficient. The latter was calculated via the equation,

$$
\Gamma_{\text {overall }}=\frac{1}{\frac{\bar{c} d}{8 D_{g}}-\frac{1}{2}+\frac{1}{\alpha}}
$$

where, $D_{g}$ is the gas phase diffusion coefficient and $\alpha$ is the mass accommodation coefficient.

The analysis assumes that species in the liquid phase are homogeneously dispersed throughout the entire droplet. This is justified as follows. The average distance travelled by diffusion in one dimension in time, $t$, is $\sqrt{2 D_{l} t}$. For a typical liquid diffusion coefficient, $D_{l}$, of $1 \times 10^{-9} \mathrm{~m}^{2} \mathrm{~s}^{-1}$ and droplet diameter of $1 \times 10^{-5} \mathrm{~m}$, a species takes only $0.013 \mathrm{~s}$ on average to diffuse to the centre of a droplet.

The 21 species for which phase transfer was included are listed in Table A11. Unless otherwise specified, data for $D_{g}$, $\alpha$ and $H$ were obtained from Herrmann et al. $(1999,2000)$. For species with no literature values of $D_{g}$, estimates were calculated using the method devised by Fuller et al. (1969).

\subsection{Liquid phase reactions}

As for the gas phase, the model included the liquid phase oxidation of organic compounds containing one carbon atom, as detailed in Tables A12 to A17. The majority of the reaction data were taken from Herrmann and co-workers (1999, 2000). Liquid phase photolysis rate coefficients were coded according to the CMD protocol (Poppe et al., 2001). Data for the aromatic chemistry in the liquid phase (Table A18) were taken from a number of sources. The rate coefficient for the reaction of benzene with $\mathrm{OH}$ was taken from Pan et al. (1993). For the reaction of phenol with $\mathrm{NO}_{3}$ a value of $1.8 \times 10^{9} \mathrm{~L} \mathrm{~mol}^{-1} \mathrm{~s}^{-1}$ was used (Barzaghi and Herrmann, 2002) which compares well with the value of $1.9 \times 10^{9} \mathrm{~L} \mathrm{~mol}^{-1} \mathrm{~s}^{-1}$ given in the UNARO report (UNARO, 2001). Rate data to describe the loss of phenol through reaction with $\mathrm{OH}$ were also taken from this latter report.

\subsection{Reactions of aromatics}

The degradation of aromatics in the troposphere is an area in which there remains a large amount of uncertainty. In this model, the benzene oxidation scheme shown in Fig. 1 was used, with data from version 3 of the MCM. Around $25 \%$ of the reaction of benzene with $\mathrm{OH}$ yields phenol, with the remaining products being ring-opened species. While the oxidation of benzene is also initiated by the $\mathrm{NO}_{3}$ radical, this is only a minor route. The rate coefficient for the reaction of benzene with $\mathrm{OH}$ at $298 \mathrm{~K}$ is $1.39 \times 10^{-12} \mathrm{~cm}^{3}$ molecule ${ }^{-1} \mathrm{~s}^{-1}$ but $<3 \times 10^{-17} \mathrm{~cm}^{3}$ molecule ${ }^{-1} \mathrm{~s}^{-1}$ for reaction with $\mathrm{NO}_{3}$ (Calvert et al., 2002). Phenol reacts with $\mathrm{OH}$ and $\mathrm{NO}_{3}$ via

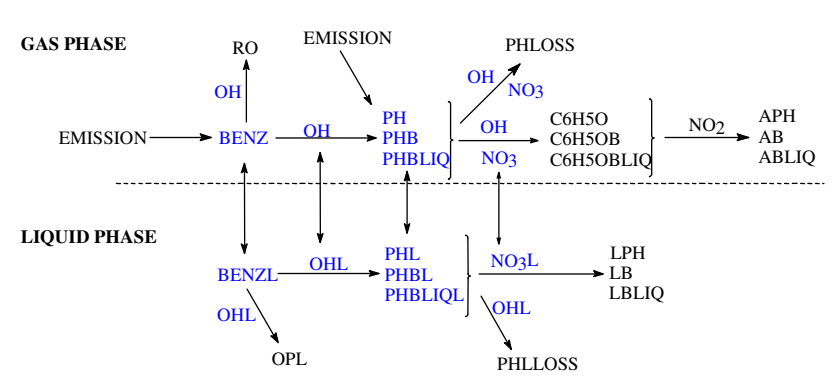

Fig. 1. Schematic of the aromatic chemistry in both the gas and liquid phases. Double headed arrows represent phase transfer between the gas and the liquid phase. The terms APH, AB, ABLIQ, LPH, LB, LBLIQ on the right-hand side of the diagram all refer to nitrophenol product but formed through different reaction paths through the scheme, as explained in Table 1 and colour-coded in Fig. 2. The other acronyms are constructed similarly, e.g. PHBL refers to phenol partitioned into the liquid phase following gas-phase oxidation of benzene.

abstraction of the phenolic hydrogen to yield the $\mathrm{C}_{6} \mathrm{H}_{5} \mathrm{O}$ intermediate which may then combine with $\mathrm{NO}_{2}$ to generate nitrophenol.

As indicated in Fig. 1, at each stage of this oxidation process the aromatic species may undergo phase transfer. Although benzene has a very small Henry's Law coefficient, those for phenol and nitrophenols are considerably greater. In the liquid phase, benzene is oxidised through reaction with $\mathrm{OH}$ to produce phenol as well as other liquid phase products. Oxidation of benzene may also be initiated by the $\mathrm{NO}_{3}$ radical. The liquid phase rate coefficient of the reaction between $\mathrm{NO}_{3}$ and benzene has been measured (Herrmann et al., 1995; Herrmann et al., 1996), but there have been no studies of the products of this reaction. The phenol present in the liquid may then react with $\mathrm{NO}_{3}$ to yield nitrophenol, or may be lost from the system through reaction with $\mathrm{OH}$. It is assumed in the model that ring-retaining nitration products are the only product of phenol nitration in the liquid phase. In their study, Barzaghi and Herrmann (2002) presented new and previous data on phenol nitration and concluded that the two isomers, 2-nitrophenol and 4-nitrophenol, were the main reaction products. However, it must be noted that a reduced yield of nitrophenols from this reaction would slightly reduce the overall influence of the liquid phase on nitrophenol production.

A number of other reaction pathways to form nitrophenol from benzene/phenol also exist in addition to those included in the model, as reviewed recently by Harrison et al. (2005). However, these authors did not propose which additional pathways, if any, to the major ones discussed above and included in our model, are likely to be competitive under atmospheric (as opposed to laboratory) conditions of reagent availability and concentrations. One potentially important simplification in our model is the assumption that reaction of phenol with $\mathrm{OH}$ does not lead to nitrophenol generation. 


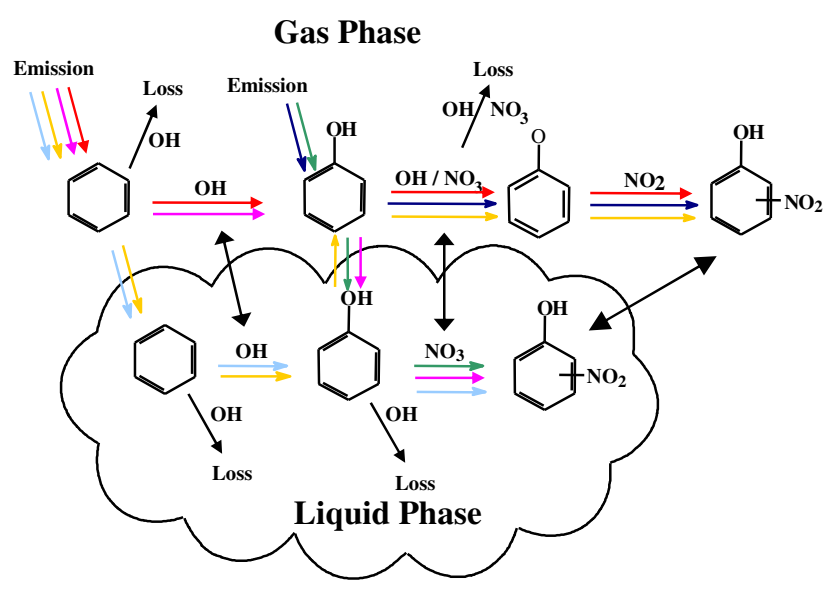

Fig. 2. Schematic of the colour scheme used to represent each different reaction path to nitrophenol formation. The different pathways are described more fully in Table 1.

Barzaghi and Herrmann (2002) proposed a route to nitrophenol formation by reaction of phenol with $\mathrm{OH}$ to form a dihydroxycyclohexadienyl radical (followed by $\mathrm{NO}_{2}$ addition) in addition to the mechanism via reaction with $\mathrm{NO}_{3}$ to form a phenoxyl radical as a first step. Although these authors reported modelling work suggesting that the reaction via $\mathrm{OH}$ could account for about $25 \%$ of the observed nitrophenol product in their experiments, they went on to conclude that the more important pathway is via the phenoxyl radical. The simplification in our model of not allowing for the possibility that some of the phenol+OH reaction yields nitrophenol will have the effect of underestimating the magnitude of liquid phase nitrophenol production, thereby offsetting the assumption discussed above that the main nitration route leads solely to ring-retaining products.

The ratio of nitrophenol isomers formed under tropospherically-relevant aqueous phase reaction remains uncertain although does now have greater consensus than when this modelling study was initiated. The observation by Barzaghi and Herrmann (2002) of 2NP:4NP product ratios in the range 60:40 to 50:50 (depending on reaction conditions) has now been supported by a very recent study by Vione et al. (2004) which reported a similar 60:40 2NP:4NP product ratio. It appears clear that aqueous phase nitration reactions of phenol do not yield the 3-nitrophenol isomer. Vione et al. (2004) observed 3NP in aqueous phase hydroxylation of nitrobenzene but the absence of $3 \mathrm{NP}$ in field measurements implies that this potential pathway is negligible as an atmospheric source of nitrophenols. In the model the ratio of the 2- and 4-nitrophenols formed was varied between the two different scenarios of predominantly $2 \mathrm{NP}$ production or predominantly $4 \mathrm{NP}$ production in order to "bracket" the range of possible product ratios. Output from the two scenarios are plotted in the same figure so that it is straightforward to interpolate the expected outcome for intermediate product ratios.
It is relevant to consider the likely loss routes of the nitrophenol products. The gas-phase rate coefficients for reaction of $\mathrm{OH}$ with 2- and 4-nitrophenol have been measured, $9 \times 10^{-13} \mathrm{~cm}^{3}$ molecule ${ }^{-1} \mathrm{~s}^{-1}$ (Atkinson et al., 1992), and estimated, $4.3 \times 10^{-12} \mathrm{~cm}^{3}$ molecule ${ }^{-1} \mathrm{~s}^{-1}$ (Kwok and Atkinson, 1995), respectively. For a gas-phase $\mathrm{OH}$ radical concentration of $10^{6} \mathrm{~cm}^{-3}$ these rate coefficients yield lifetimes for 2- and 4-nitrophenol of $\sim 13$ and $\sim 3$ days, respectively. The measured upper limit to the rate coefficient for the reaction of 2-nitrophenol with $\mathrm{NO}_{3}$ is $2 \times 10^{-14} \mathrm{~cm}^{3}$ molecule ${ }^{-1} \mathrm{~s}^{-1}$ (Atkinson et al., 1992). Assuming a similar value for the analogous reaction of 4 nitrophenol (no data available), and a gas-phase $\mathrm{NO}_{3}$ radical concentration of $2 \times 10^{8} \mathrm{~cm}^{-3}$, yields a lifetime of $>\sim 2$ day, but probably considerably longer. The aqueousphase rate coefficients for reaction of $\mathrm{OH}$ with 2- and 4nitrophenol are $9.2 \times 10^{9} \mathrm{M}^{-1} \mathrm{~s}^{-1}$ and $3.8 \times 10^{9} \mathrm{M}^{-1} \mathrm{~s}^{-1}$, respectively (Barzaghi and Herrmann, 2004), which for an average aqueous phase $\mathrm{OH}$ concentration of $\sim 10^{-13} \mathrm{M}$ yields lifetimes of $\sim 0.3 \mathrm{~h}$ and $0.7 \mathrm{~h}$ respectively. The corresponding aqueous-phase rate coefficients for reaction with $\mathrm{NO}_{3}$ are $2.3 \times 10^{7} \mathrm{M}^{-1} \mathrm{~s}^{-1}$ (Barzaghi and Herrmann, 2004) and $7.1 \times 10^{7} \mathrm{M}^{-1} \mathrm{~s}^{-1}$ (Umschlag et al., 2002), respectively, which for an average $\mathrm{NO}_{3}$ concentration of $10^{-13} \mathrm{M}$ yields lifetimes of $\sim 5$ and $\sim 2$ days, respectively. Thus, of the above, only the aqueous phase reaction with $\mathrm{OH}$ is a fast loss process for the nitrophenol products. However, as demonstrated in the model (see later), the vast majority of nitrophenol product formed in the aqueous phase rapidly equilibrates back into the gas-phase (within a diffusion timescale of seconds) so that nitrophenol product will not be subject to loss by the aqueous-phase $\mathrm{OH}$ reaction.

\section{Results and discussion}

The model was coded so that the different routes to formation of nitrophenol could be tracked. These routes are colour coded in the schematic in Fig. 2 and summarised with the nomenclature used here in Table 1. The same colour scheme is used in a number of the results graphs. Liquid phase processes are defined as those in which there has been a contribution from the liquid phase in the formation of the nitrophenols. These are represented by solid colours; the hatched colours signify the two gas phase only routes. The following additional abbreviations are used: NP2 and NP4 for 2and 4-nitrophenol, respectively, present in the gas phase; and NP2L and NP4L for 2- and 4-nitrophenol present in the liquid phase. By comparing the route of formation with the final concentrations of the nitrophenols in each phase, it was possible to determine whether the nitrophenol produced in the gas phase was solely produced by gas phase reaction or whether liquid phase processes were involved. Model output is for a model simulation of two days and graphs show 
Table 1. Descriptions of the possible reaction pathways to nitrophenol formation with the associated colours and coding used in the figures. See Fig. 2 for a comparative schematic of the pathways. The prefixes A and $\mathrm{L}$ in the acronyms indicate that the final step to nitrophenol production occurs in the air (i.e. gas-phase), or liquid (i.e. aqueous-phase), respectively, whilst the terms PH and B refer to phenol and benzene, respectively. LIQ indicates a pathway involving liquid phase oxidation of benzene to phenol.

\begin{tabular}{lcc}
\hline Description of reaction pathway & Colour code in Fig. 2 & Model code for product \\
\hline $\begin{array}{l}\text { Gas phase nitrophenol produced by gas phase reaction of phenol that was } \\
\text { originally emitted into the gas phase }\end{array}$ & hatched blue & APH \\
\hline $\begin{array}{l}\text { Gas phase nitrophenol formed from gas phase phenol produced from benzene } \\
\text { by gas phase reaction }\end{array}$ & hatched red & AB \\
\hline $\begin{array}{l}\text { Gas phase nitrophenol formed from gas phase phenol produced from benzene } \\
\text { by liquid phase reaction }\end{array}$ & orange & ABLIQ \\
\hline $\begin{array}{l}\text { Liquid phase nitrophenol produced by the liquid phase reaction of phenol that } \\
\text { was originally emitted into the gas but then partitioned into the liquid phase }\end{array}$ & green & LPH \\
\hline $\begin{array}{l}\text { Liquid phase nitrophenol formed from gas phase phenol produced from ben- } \\
\text { zene by gas phase reaction }\end{array}$ & pink & LB \\
\hline $\begin{array}{l}\text { Liquid phase nitrophenol formed from liquid phase phenol produced from } \\
\text { benzene by liquid phase reaction. }\end{array}$ & cyan & LBLIQ \\
\hline
\end{tabular}

time-series snapshots of output rather than integrated over the run-time.

\subsection{Effect of the liquid phase}

Figure 3 shows the modelled relative rate of total nitrophenol production through the various pathways at $278 \mathrm{~K}$. As expected, the liquid phase (all solid colours) becomes a more important route for the production of nitrophenols as the liquid water content is increased. For the driest scenario $\left(L_{c}=3 \times 10^{-9}\right)$, less than $2 \%$ of nitrophenol production is via liquid phase processes, increasing to over $93 \%$ under the wettest conditions modelled $\left(L_{c}=3 \times 10^{-6}\right)$. At the "benchmark" $L_{c}$ value of $3 \times 10^{-7}, 58 \%$ of nitrophenol production occurs via liquid phase processes. The model clearly shows that nitrophenol production is sensitive to realistic values of $L_{c}$. It is also apparent from Fig. 3 that the routes of nitrophenol production via oxidation of benzene to phenol in the liquid phase, LBLIQ (cyan) and ABLIQ (orange), are not significant at any value of $L_{c}$. This indicates that the low aqueous solubility of benzene is not sufficiently offset by fast aqueous phase reaction to compete with nitrophenol production via phenol.

Figure 4 shows how the nitrophenol generated by the routes illustrated in Fig. 3 is actually partitioned between the gas and liquid phases. The liquid phase product ratio for 2- and 4-nitrophenol is not known, and since the two nitrophenols have significantly different Henry's Law values, the modelled atmospheric partitioning of these products depends on the assumed product ratio, as illustrated by Figs. $4 \mathrm{a}$ and $\mathrm{b}$ (for which 2-nitrophenol:4-nitrophenol product ratios of 90:10 and 10:90, respectively, were assumed). In each

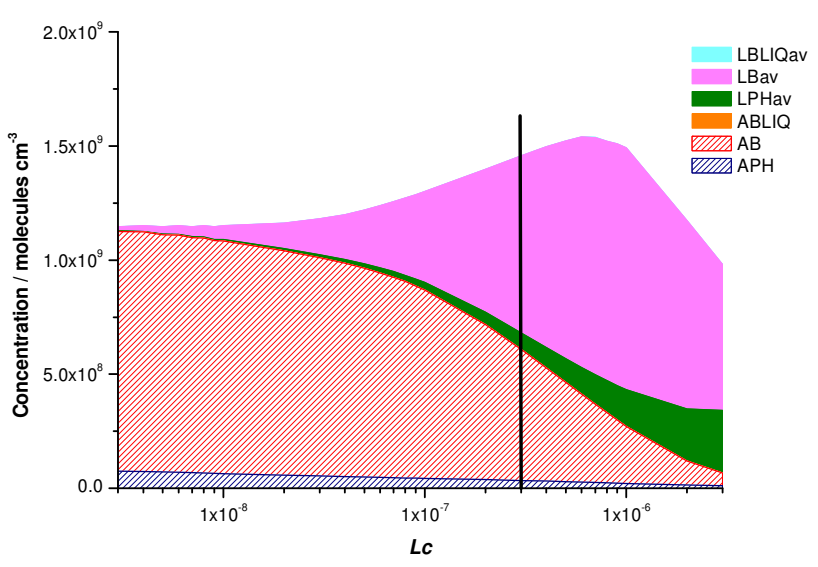

Fig. 3. The relative importance of the different nitration pathways at $278 \mathrm{~K}$ as a function of $L_{c}$.

case, for the driest scenario, the nitration of phenol is dominated by the gas phase reaction path (hatched colours) which only generates 2-nitrophenol. Since 2-nitrophenol has a relatively low Henry's Law coefficient $\left(385 \mathrm{M} \mathrm{atm}^{-1}\right.$ at $278 \mathrm{~K}$ ) it remains almost exclusively in the gas phase. Figure $4 \mathrm{a}$ shows that even for the wetter scenarios, 2-nitrophenol remains the dominant product. This is a consequence of the dominance of 2-nitrophenol in the product ratio assumed in this scenario. The proportion of 4-nitrophenol is considerably greater in scenario Fig. $4 \mathrm{~b}$ where, for an $L_{c}$ value of $3 \times 10^{-7}$, 4-nitrophenol accounts for $52 \%$ of the total nitrophenol produced, reflecting the larger proportion of liquid phase reactions that generate 4-nitrophenol. However, while 

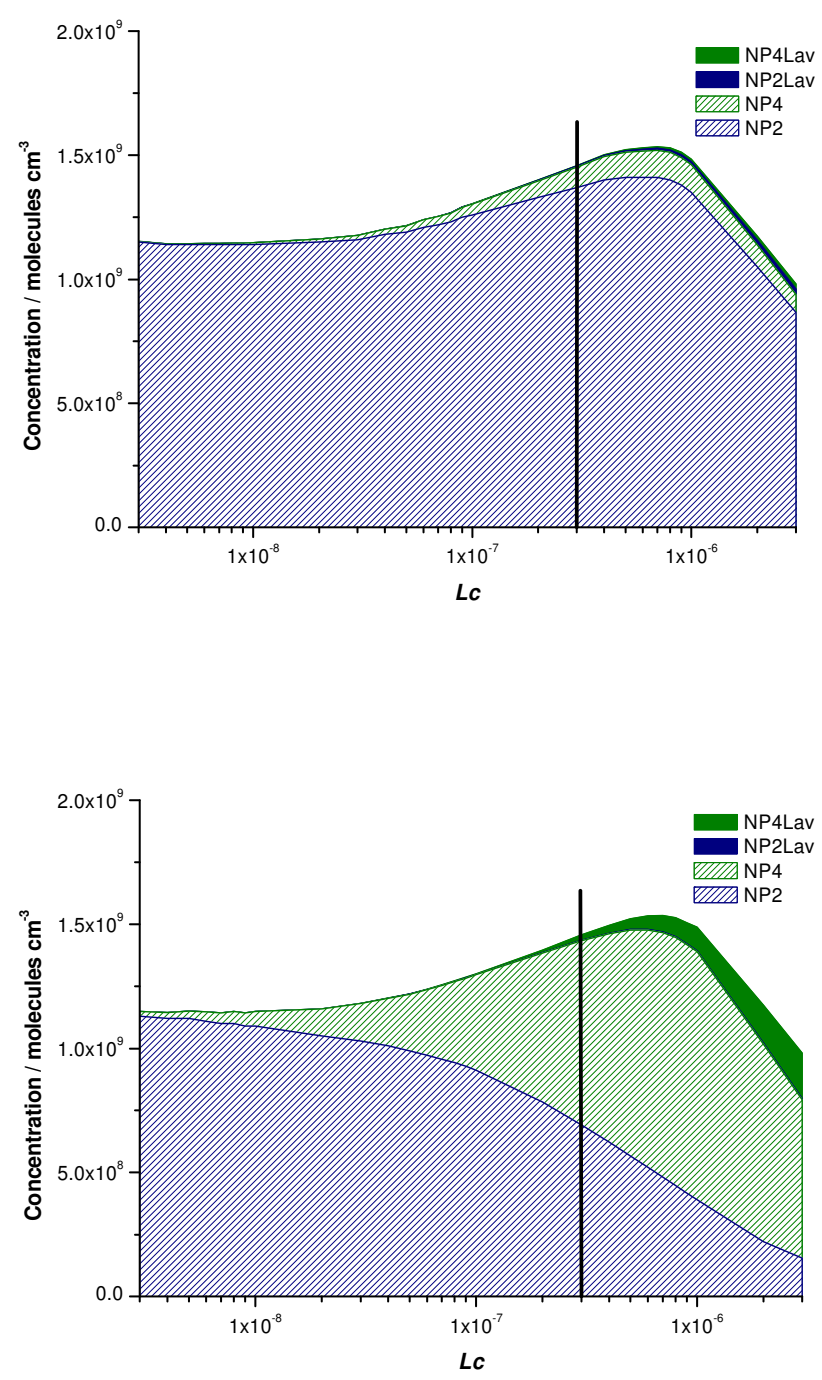

Fig. 4. The ratio of nitrophenols produced at $278 \mathrm{~K}$ as a function of $L_{c}$ with the liquid phase reaction of $\mathrm{NO}_{3}$ with phenol yielding (a) 90\% 2-nitrophenol and 10\% 4-nitrophenol and (b) $90 \% 4$ nitrophenol and $10 \%$ 2-nitrophenol.

the relative amount of 2- or 4-nitrophenol has changed between these two scenarios, the total amount of nitrophenol partitioned into the liquid phase remains low (solid colours); for $L_{c}=3 \times 10^{-7}$ only $0.4 \%$ and $1.6 \%$ of nitrophenol is in the liquid phase for scenarios (a) and (b), respectively. These latter proportions can be compared with the fraction, $f_{w}$, expected in the aqueous phase for equilibrium partitioning of the nitrophenols between the phases:

$f_{w}=1-\frac{1}{\left(1+L_{c} H R T\right)}$

For example, using the Henry's Law data contained in Table A11, the calculated $f_{w}$ values at $T=278 \mathrm{~K}$ and $L_{c}=3 \times 10^{-7}$ are $0.5 \%$ and $2 \%$ for the two scenarios of $90: 10$

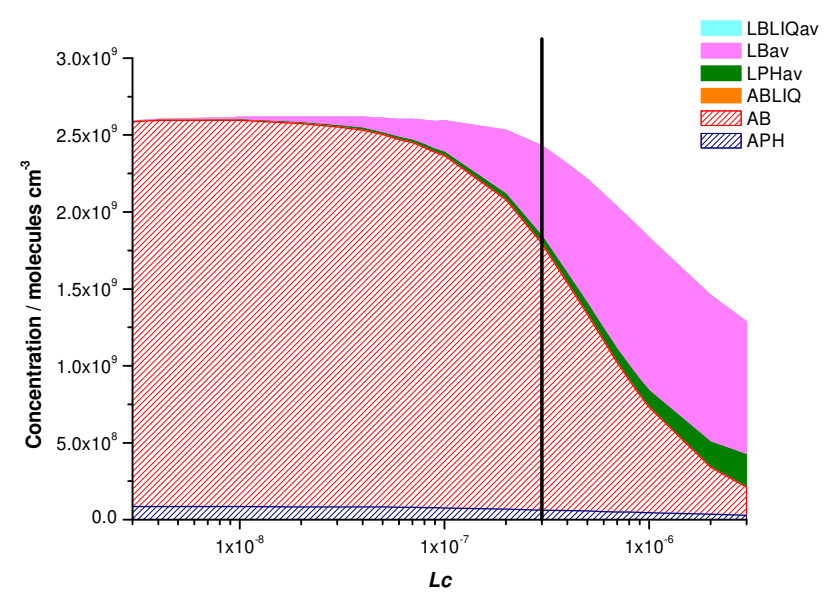

Fig. 5. The relative importance of the different nitration pathways at $298 \mathrm{~K}$ as a function of $L_{c}$.

or 10:90 2NP:4NP, respectively, which match those shown in Fig. 4.

Thus the key observation from comparison of Figs. 3 and 4 is that the contribution of the liquid phase to the production of nitrophenol (solid colours, Fig. 3) is much larger than the fraction of nitrophenol that is observed in the liquid phase (solid colours, Fig. 4). For example, when $L_{c}=3 \times 10^{-7}$ the liquid phase accounts for $58 \%$ of the total rate of nitrophenol production but $<2 \%$ of the nitrophenol distribution. This indicates that a considerable proportion of nitrophenol observed in the gas phase may actually be produced via liquid phase pathways and, being a less soluble product, equilibrate back into the gas phase.

\subsection{Effect of temperature}

Figures 5 and 6 show results for a temperature of $298 \mathrm{~K}$. The rate of nitrophenol production was greater at $298 \mathrm{~K}$ (Fig. 5) than at $278 \mathrm{~K}$ (Fig. 3) over the whole range of $L_{c}$ values. For example, for $L_{c}=3 \times 10^{-7}$, nitrophenol production was almost 1.7 times greater at $298 \mathrm{~K}$ than at $278 \mathrm{~K}$. On the other hand, the proportion of nitrophenol produced through liquid phase processes at $L_{c}=3 \times 10^{-7}$ decreases from $58 \%$ at $278 \mathrm{~K}$ (solid colours, Fig. 3) to $26 \%$ at $298 \mathrm{~K}$ (solid colours, Fig. 5). The former observation is due to the general increase in reaction rates at higher temperature, while the latter observation is due to the reduction in aqueous solubility with temperature. (Note that such an interpretation is somewhat over-simplistic; multiphase tropospheric chemistry consists of many processes affected differently by changes in temperature so whilst, for example, higher temperature may increase the rates of reactions from precursor to nitrophenol, it is likely also to increase the rate of competing precursor loss processes).

Figures $6 \mathrm{a}$ and $\mathrm{b}$ show that, at an $L_{c}$ value of $3 \times 10^{-7}$, the proportion of nitrophenol actually partitioned in the liquid 
phase is only $<0.1 \%$ and $0.2 \%$, respectively (solid colours). These proportions again reflect the equilibrium partitioning of nitrophenol in the liquid phase for these conditions. The proportions of nitrophenol in the liquid phase are lower than the equivalent proportions of $0.4 \%$ and $1.6 \%$ at $278 \mathrm{~K}$ (Fig. 4), despite the greater total production rate of nitrophenol at the higher temperature, because of the lower Henry's Law coefficients at higher temperatures, i.e., $H$ values decline markedly with increased temperature, so there is substantially less reagent, both radical and other, transferred into the liquid phase. The reduced liquid phase nitrophenol production also affects the nitrophenol isomer ratio. At an $L_{c}$ value of $3 \times 10^{-7}$, 4-nitrophenol comprises $6 \%$ and $52 \%$ of total nitrophenol produced at $278 \mathrm{~K}$ for scenarios (a) and (b) respectively, compared with $3 \%$ and $24 \%$ at $298 \mathrm{~K}$.

Comparison of the proportions of solid colours in Figs. 5 and 6 again emphasises that a considerable proportion of nitrophenol ultimately partitioned in the gas phase may actually be formed in the liquid phase. For example, for $L_{c}=3 \times 10^{-7}$, the liquid phase contributes $26 \%$ to total production of nitrophenol but $<\sim 0.2 \%$ to the ultimate phase partitioning of the nitrophenol.

3.3 Sensitivity towards the liquid phase reaction rate coefficients

An important application of models is to investigate the sensitivity of output to variations in parameters whose values may be uncertain. One parameter for which laboratory data are sparse is the liquid phase reaction rate coefficient between benzene and $\mathrm{OH}$. Although Figs. 3 and 6 suggest that this reaction is only a minor route in the production of nitrophenols (cyan and orange colours in the figures), it is possible that a change to this rate coefficient might cause a large effect upon the system as a whole. However, simulations show that nitrophenol production at $L_{c}=3 \times 10^{-7}$ is unaffected even when this rate coefficient is increased by two orders of magnitude. Only under the very wettest conditions is any nitrophenol formed via an increased rate of liquid phase reaction between benzene and $\mathrm{OH}$, and even in this scenario this route contributes only $2.4 \%$ to nitrophenol production.

The effect of changing the rate coefficient for the reaction between phenol and $\mathrm{NO}_{3}$ to either $1.8 \times 10^{8} \mathrm{~L} \mathrm{~mol}^{-1} \mathrm{~s}^{-1}$ or $1.8 \times 10^{10} \mathrm{~L} \mathrm{~mol}^{-1} \mathrm{~s}^{-1}$ is shown in Figs. $7 \mathrm{a}$ and $\mathrm{b}$, respectively. The base scenario for comparison is Fig. 5, in which the value of the rate coefficient is $1.8 \times 10^{9} \mathrm{~L} \mathrm{~mol}^{-1} \mathrm{~s}^{-1}$, as reported by Herrmann and co-workers (Barzaghi and Herrmann, 2002; Umschlag et al., 2002). When $L_{c}$ is small $\left(<\sim 10^{-8}\right)$, reactions in the liquid phase are not important, and changes to this rate coefficient have no impact on nitrophenol production (the cyan, pink and green coloured routes in the figures). In contrast, for $L_{c}>\sim 10^{-8}$, comparison of Figs. 5 and 7 show that an increase in phenol $+\mathrm{NO}_{3}$ rate coefficient leads to a large increase in the amount of nitrophenol produced in the liquid phase, and vice versa.
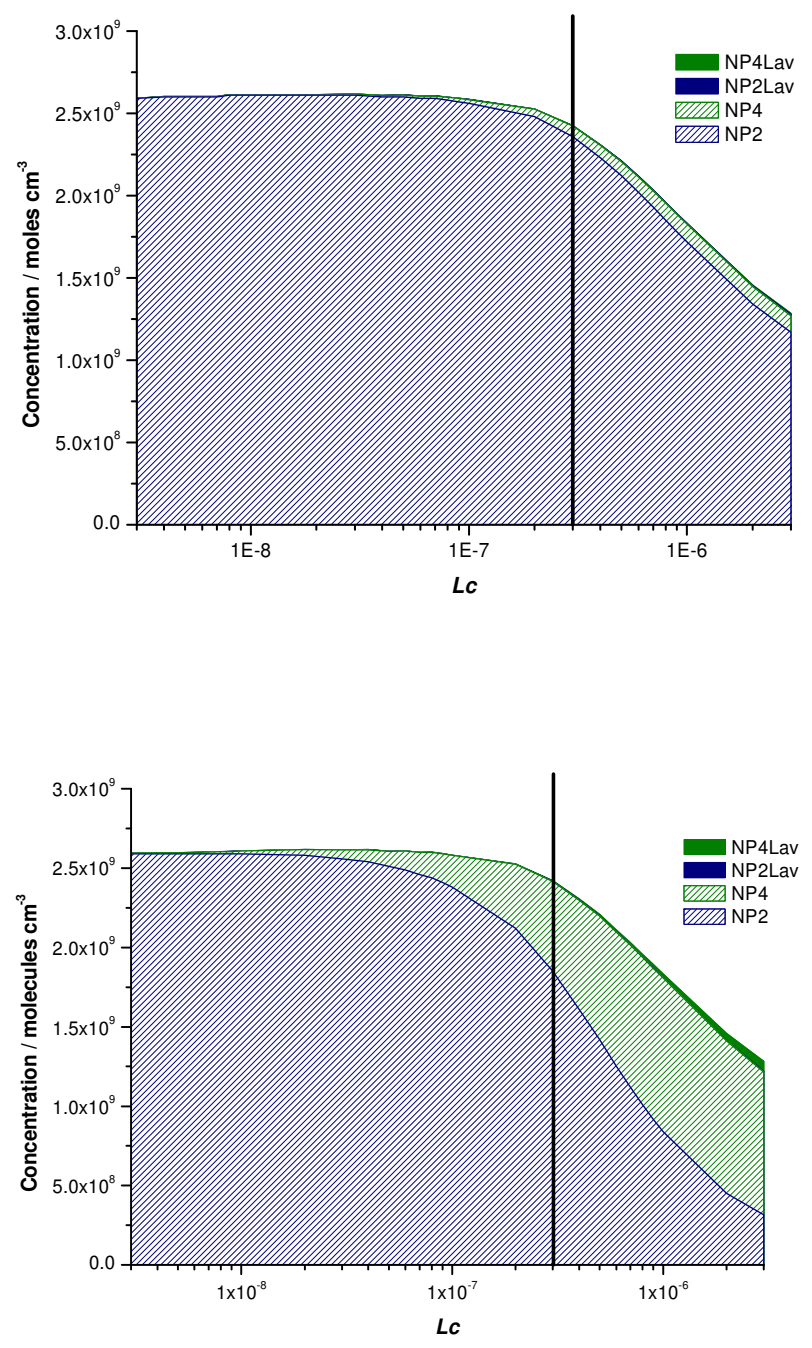

Fig. 6. The ratio of nitrophenols produced at $298 \mathrm{~K}$ as a function of $L_{c}$ with the liquid phase reaction of $\mathrm{NO}_{3}$ with phenol yielding (a) 90\% 2-nitrophenol and 10\% 4-nitrophenol and (b) 90\% 4nitrophenol and $10 \%$ 2-nitrophenol.

For $L_{c}=3 \times 10^{-7}$, the proportion of nitrophenol produced in the liquid phase is $26 \%$ when the rate coefficient has the best-estimate value of $1.8 \times 10^{9} \mathrm{~L} \mathrm{~mol}^{-1} \mathrm{~s}^{-1}$ (solid colours, Fig. 5), but is $4 \%$ or $67 \%$ when the value of this rate coefficient is decreased, or increased, respectively, by an order of magnitude (solid colour, Fig. 7).

Variation in the liquid phase phenol $+\mathrm{NO}_{3}$ rate coefficient also impinges upon the amount of nitrophenol produced via the gas phase. This is because the liquid phase reaction between phenol and $\mathrm{NO}_{3}$ also acts as an effective loss route for $\mathrm{NO}_{3}$, increasing the gas-to-liquid phase transfer of this radical and reducing its concentration in the gas phase. The hatched colour portions of Figs. 5 and $7 \mathrm{~b}$ show that increasing the rate coefficient from $1.8 \times 10^{9} \mathrm{~L} \mathrm{~mol}^{-1} \mathrm{~s}^{-1}$ to $1.8 \times 10^{10} \mathrm{~L} \mathrm{~mol}^{-1} \mathrm{~s}^{-1}$ for an $L_{c}$ value of $3 \times 10^{-7}$ reduces the amount of gas phase production of nitrophenol by $\sim 25 \%$. 

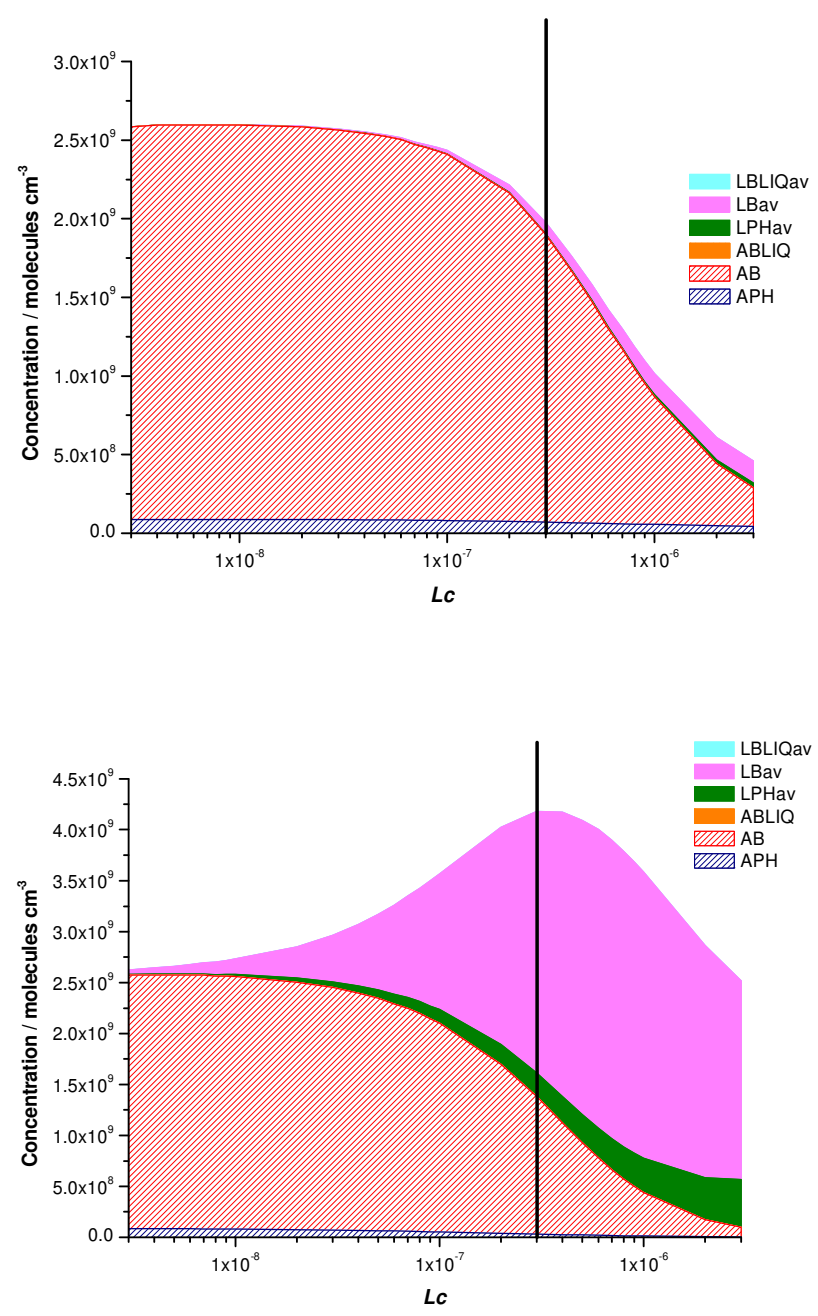

Fig. 7. The relative importance of the different nitration pathways at $298 \mathrm{~K}$ with the phenol $+\mathrm{NO}_{3}$ liquid phase reaction rate coefficient set at (a) $1.8 \times 10^{8} \mathrm{~L} \mathrm{~mol}^{-1} \mathrm{~s}^{-1}$ and (b) $1.8 \times 10^{10} \mathrm{~L} \mathrm{~mol}^{-1} \mathrm{~s}^{-1}$ (compare with Fig. 5 for rate coefficient of $1.8 \times 10^{9} \mathrm{~L} \mathrm{~mol}^{-1} \mathrm{~s}^{-1}$ ).

This effect is likely further enhanced at lower temperatures (since lower temperatures also increase liquid phase transfer), although it would also depend on the degree of temperature dependence of the rate coefficient.

An equally important process is the reaction of phenol with $\mathrm{OH}$ which competes with the nitration reaction. The UNARO report (UNARO, 2001) gives a rate coefficient of $6.6 \times 10^{9} \mathrm{~L} \mathrm{~mol}^{-1} \mathrm{~s}^{-1}$ for the phenol+OH reaction at $298 \mathrm{~K}$, as used in the base scenario depicted in Fig. 5. Figure 8a and $b$ show the effect of changing this rate coefficient value to $6.6 \times 10^{8} \mathrm{~L} \mathrm{~mol}^{-1} \mathrm{~s}^{-1}$ and $6.6 \times 10^{10} \mathrm{~L} \mathrm{~mol}^{-1} \mathrm{~s}^{-1}$, respectively. As before, for liquid water content $<\sim 10^{-8}$, changes to the liquid phase reaction rate have little effect on production of nitrophenol. For higher values of liquid water content, a higher value of the phenol+OH rate coefficient leads to less nitrophenol production. But changes in the rate of this reac-
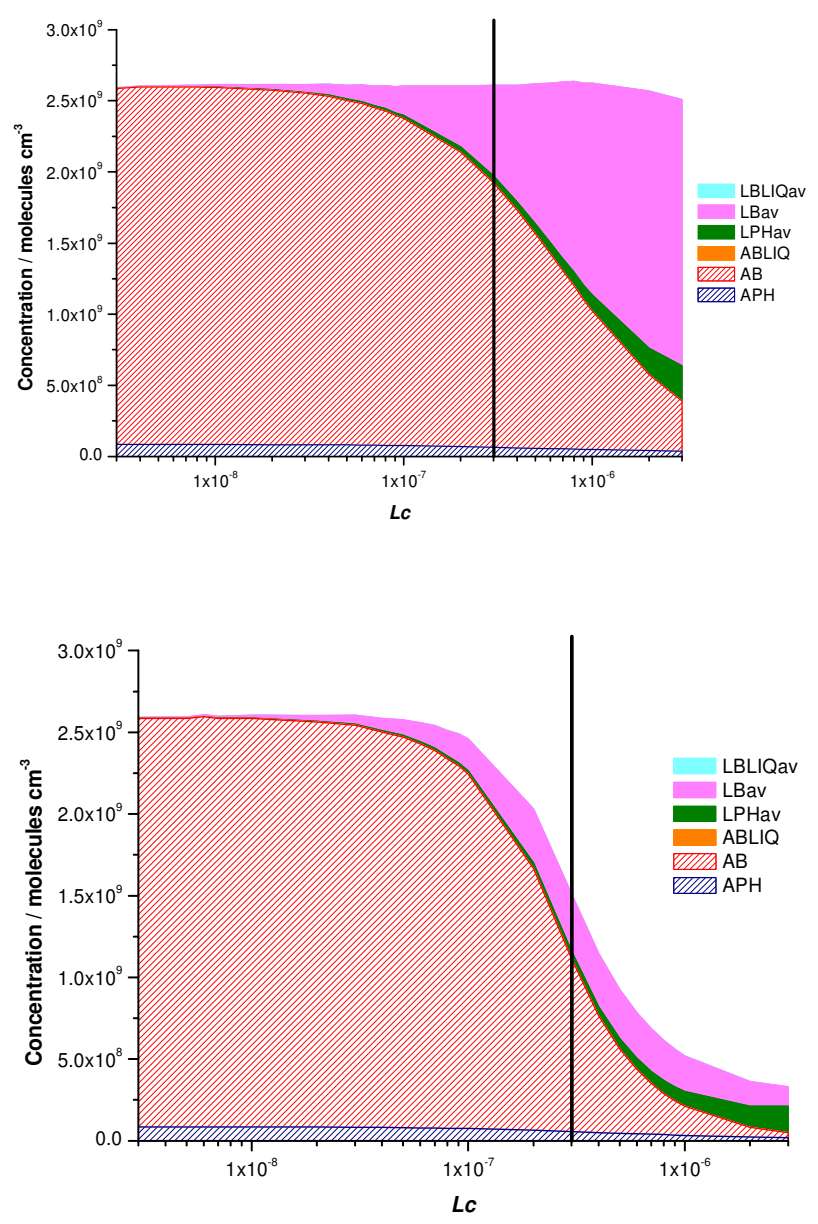

Fig. 8. The relative importance of the different nitration pathways at $298 \mathrm{~K}$ with the phenol $+\mathrm{OH}$ liquid phase reaction rate coefficient set at (a) $6.6 \times 10^{8} \mathrm{~L} \mathrm{~mol}^{-1} \mathrm{~s}^{-1}$ and (b) $6.6 \times 10^{10} \mathrm{~L} \mathrm{~mol}^{-1} \mathrm{~s}^{-1}$. (Compare with Fig. 5 for rate coefficient of $\left.6.6 \times 10^{9} \mathrm{~L} \mathrm{~mol}^{-1} \mathrm{~s}^{-1}\right)$.

tion also give rise to changes in nitrophenol production in the gas phase (comparison of the hatched portions of Figs. 5 and 8 ). This is because the liquid phase reaction between phenol and $\mathrm{OH}$ also acts as a loss route for $\mathrm{OH}$. Increasing the gas-to-liquid phase transfer of $\mathrm{OH}$ slows the rate of gas phase oxidation of benzene to phenol to nitrophenol, as illustrated in Fig. 1.

\subsection{Effect of droplet diameter}

As justified above, the base scenario droplet diameter was $1 \times 10^{-5} \mathrm{~m}$. Figure $9 \mathrm{a}$ and $\mathrm{b}$ shows the effect of assuming that liquid water content was dispersed in droplets of diameter $1 \times 10^{-4} \mathrm{~m}$ or $1 \times 10^{-6} \mathrm{~m}$, respectively (Fig. 5 is the comparative output for $d=1 \times 10^{-5} \mathrm{~m}$ at $T=298 \mathrm{~K}$ ). From Figs. 5 and 9 the proportion of nitrophenol produced by liquid phase processes (solid colours) is 37, 26 and $5 \%$ when $d=1 \times 10^{-6}$, $1 \times 10^{-5}$ and $1 \times 10^{-4} \mathrm{~m}$, respectively, for $L_{c}=3 \times 10^{-7}$. For a given $L_{c}$ value, a smaller droplet diameter means a larger 
liquid phase specific area, $A_{c}$, which changes the phasetransfer kinetics because the uptake coefficient, $\Gamma_{\text {overall }}$, is inversely proportional to $d$ (Eq. 5). (Changing $d$ at a given $L_{c}$ does not change the equilibrium Henry's law phase partitioning, although larger droplets may reduce liquid phase mixing). In interpreting Fig. 9 it must also be remembered that $L_{c}$ values at the ends of the modelled range are likely to be associated with different droplet diameters in reality. The smallest modelled $L_{c}$ value $\left(3 \times 10^{-9}\right)$ is more typical of mist/haze, which is unlikely to consist of droplets as large even as $1 \times 10^{-5} \mathrm{~m}$. Likewise, the largest modelled $L_{c}$ value $\left(3 \times 10^{-9}\right)$ corresponds to a heavy condensed phase event such as fog, for which droplet diameters in the range $1 \times 10^{-5}$ to $1 \times 10^{-4} \mathrm{~m}$ are most plausible.

Although a smaller droplet diameter increases the proportion of nitrophenol production in the liquid phase it decreases total nitrophenol production overall (Fig. 9b). As well as its direct impact on species that undergo phase transfer, a change in liquid phase specific area also indirectly impacts upon reactions of other species (in both phases) that do not undergo phase transfer. For example, when $d$ is smaller, the gas phase concentrations of both $\mathrm{OH}$ and $\mathrm{NO}_{3}$ (which do undergo phase transfer) are reduced, while in the liquid phase $\mathrm{NO}_{3}$ is reduced but $\mathrm{OH}$ is increased, and these changes will have an effect on rates of other reactions. In the gas phase both $\mathrm{OH}$ and $\mathrm{NO}_{3}$ affect both production and loss of nitrophenol, while in the liquid phase increased $\mathrm{OH}$ concentration limits nitrophenol production by removing phenol. As the effect of the liquid phase is enhanced at the smaller droplet size, this increase in liquid phase phenol+OH loss reaction has the overall effect of reducing the total amount of nitrophenol produced.

\subsection{Comparison of model results with field observations}

Model simulations of nitrophenol concentration were compared against the reported field data summarised in Table 2. Only general comparisons can be undertaken since the model was zero-dimensional and monodisperse and did not include emissions or concentration data specific to any particular field campaign.

The data presented in Figs. 3 to 9 are model simulations of two days, chosen to represent a reasonable air-mass processing time. The gas phase nitration of phenol is thought to yield mainly 2-nitrophenol so model simulations incorporating this as the dominant product of this reaction are most appropriate. Thus, the field data are compared in Table 2 with the model simulated data corresponding to Fig. $4 \mathrm{a}$ (i.e. best-guess base scenario, $T=278 \mathrm{~K}$ ). The model data are for $L_{c}=3 \times 10^{-7}$ and have been converted to the appropriate units of $\mathrm{ng} \mathrm{m}^{-3}$ and $\mu \mathrm{g} \mathrm{L}^{-1}$.

Table 2 shows that model simulated data are of an appropriate order of magnitude; for example, the value of $160 \mathrm{ng} \mathrm{m}^{-3}$ generated by the model for 2-nitrophenol in the gas phase is between the values of $350 \mathrm{ng} \mathrm{m}^{-3}$ measured at
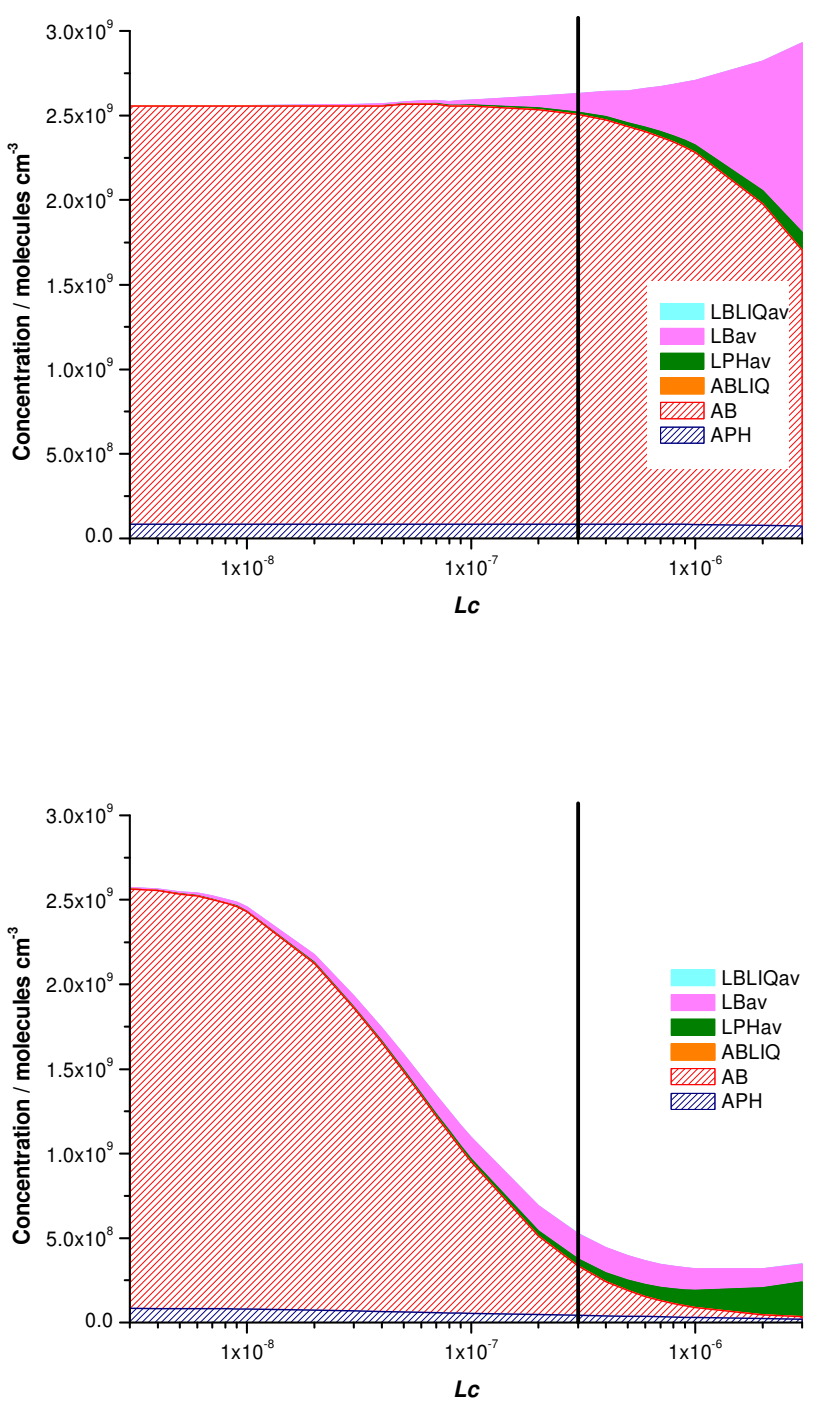

Fig. 9. The relative importance of the different nitration pathways at $298 \mathrm{~K}$ with monodisperse liquid droplet diameter of (a) $1 \times 10^{-4} \mathrm{~m}$ and (b) $1 \times 10^{-6} \mathrm{~m}$ (compare with Fig. 5 for diameter $1 \times 10^{-5} \mathrm{~m}$ ).

an urban site in Switzerland, and $24 \mathrm{ng} \mathrm{m}^{-3}$ measured at an urban site, in Oregon. The smaller concentrations of 0.8$6.4 \mathrm{ng} \mathrm{m}^{-3}$ were measured at the remote site at Great Dun Fell (GDF). In addition to the atmospheric formation of nitrophenols by the routes indicated here, the observed data in Table 2 from urban areas may include nitrophenol emitted from primary sources such as car exhaust which is not considered in the model. Field measurements for 4-nitrophenol in the gas phase are only available from the GDF campaign $\left(1.2-35 \mathrm{ng} \mathrm{m}^{-3}\right)$ and from Rome $\left(\sim 22 \mathrm{ng} \mathrm{m}^{-3}\right)$. The model simulated concentrations $\left(170 \mathrm{ng} \mathrm{m}^{-3}\right)$ are somewhat higher, although still reasonably consistent given that the model was not set up to simulate a particular real scenario.

At GDF, concentrations of 4-nitrophenol were generally higher than those for 2-nitrophenol (Table 2), whereas they 
Table 2. Measurements of 2- and 4-nitrophenol in cloudwater and the gas phase. Note that simultaneous measurement of concentrations in both phases has only been undertaken in the Great Dun Fell field campaign. Model simulation data correspond to Fig. 4a and are for two days at $278 \mathrm{~K}$, with a volume fraction liquid water content of $3 \times 10^{-7}$, and assumed branching ratio for the reaction of phenol with $\mathrm{NO}_{3}$ of 90\% 2-nitrophenol and 10\% 4-nitrophenol.

\begin{tabular}{|c|c|c|c|c|}
\hline & \multicolumn{2}{|c|}{ Field observations } & \multicolumn{2}{|c|}{ Model simulations (this study) } \\
\hline & Gas phase/ng m ${ }^{-3}$ & Cloud $/ \mu \mathrm{g} \mathrm{L}^{-1}$ & Gas phase/ng m ${ }^{-3}$ & Cloud $/ \mu \mathrm{g} \mathrm{L}^{-1}$ \\
\hline 2-nitrophenol & $\begin{array}{c}0.8-6.4^{a} \\
24^{b} \\
350^{d} \\
\sim 14^{e}\end{array}$ & $\begin{array}{c}0.02-0.6^{a} \\
0.3^{c}\end{array}$ & $160\left(6.9 \times 10^{8}\right)^{g}$ & 1.4 \\
\hline 4-nitrophenol & $\begin{array}{l}1.2-35^{a} \\
\sim 22^{e}\end{array}$ & $\begin{array}{c}0.05-4.9^{a} \\
1.7-16.3^{f} \\
21^{c} \\
5.4^{c}\end{array}$ & $170\left(7.4 \times 10^{8}\right)^{g}$ & 16 \\
\hline
\end{tabular}

${ }^{a}$ Great Dun Fell, England (Lüttke et al., 1997)

${ }^{b}$ Portland, Oregon (Leuenberger et al., 1985)

${ }^{c}$ Mount Brocken, Germany (Lüttke et al., 1999)

$d$ urban site, Switzerland (Leuenberger et al., 1988)

$e$ urban site, Rome, gas and particle-bound (Cecinato et al., 2005)

$f$ Vosges mountains, France (Levsen et al., 1990)

$g$ Values in parenthesis are gas phase concentrations in units of molecules $\mathrm{cm}^{-3}$

are more similar for measurements in Rome and for the model data. The comparison is almost irrelevant because the model data relies on an assumption of 2-nitrophenol to 4-nitrophenol ratio.

Liquid phase nitrophenol measurements are available only for less polluted environments. Again the effect of the presumed pollution burden of the air mass can be seen with the values at Mount Brocken and the Vosges Mountains generally higher than those observed at the more remote site at GDF. Considering the lack of observational data at urban sites, the concentrations obtained by the model agree favourably with those values obtained by field work studies.

The only primary emission data available for nitrophenols are isolated measurements of some vehicle exhausts, reported to be up to the $\mathrm{mg} \mathrm{m}^{-3}$ range (Nojima et al., 1983; Tremp et al., 1993). There are no inventory data. It is therefore not possible reliably to estimate how much nitrophenol measured in the atmosphere is derived from primary sources. Whilst primary emissions may be important in the immediate roadside environment, it seems likely that the majority of atmospheric nitrophenol is of secondary origin as described here.

\section{Conclusions}

A box model of relevant multiphase tropospheric chemistry has shown that liquid water cloud/rain drops can contribute significantly to the formation of 2- and 4-nitrophenol from benzene and phenol emitted into the troposphere in the gas phase. The partitioning of nitrophenol product back into the gas phase often obscures the fact that a significant proportion of measured gas phase nitrophenol is produced through liquid phase reactions. The results emphasise the importance of ensuring that both liquid and gas phase processes are included for a complete understanding of the sources and fates of certain tropospheric species. 


\section{Appendix A}

Table A1. Concentrations of time-independent gas phase species.

\begin{tabular}{ll}
\hline Species & Concentration/molecules cm $\mathrm{cm}^{-3}$ \\
\hline $\mathrm{O}_{2}$ & $5.1 \times 10^{18}$ \\
$\mathrm{H}_{2} \mathrm{O}$ & $5.1 \times 10^{17}$ \\
$\mathrm{CO}$ & $5.1 \times 10^{12}$ \\
$\mathrm{CH}_{4}$ & $4.34 \times 10^{13}$ \\
$\mathrm{CO}_{2}$ & $9.5 \times 10^{15}$ \\
$\mathrm{RH}_{\text {(alkane) }}$ & $2.55 \times 10^{11}$ \\
$\mathrm{RO}_{2}$ (alkyl peroxy radical) & $3 \times \mathrm{CH}_{3} \mathrm{O}_{2}{ }^{a}$ \\
\hline
\end{tabular}

$a$ estimated value to achieve a stable radical budget

Table A2, Initial concentrations of time-dependent gas phase species.

\begin{tabular}{ll}
\hline Variable & Initial concentration/molecules $\mathrm{cm}^{-3}$ \\
\hline $\mathrm{O}^{1} \mathrm{D}$ & $5 \times 10^{3}$ \\
$\mathrm{O}^{3} \mathrm{P}$ & $5 \times 10^{3}$ \\
$\mathrm{~N}_{2} \mathrm{O}$ & $7.5 \times 10^{12}$ \\
$\mathrm{CH}_{3} \mathrm{NO}_{3}$ & $6 \times 10^{8}$ \\
$\mathrm{CH}_{3} \mathrm{O}_{2} \mathrm{NO}_{2}$ & $1 \times 10^{6}$ \\
$\mathrm{PH}$ & $2.55 \times 10^{8} a$ \\
$\mathrm{NO}_{3}$ & $1.6 \times 10^{7} b$ \\
$\mathrm{BENZ}$ & $1.68 \times 10^{11 a}$ \\
$\mathrm{OH}$ & $5 \times 10^{3}$ \\
$\mathrm{HO}_{2}$ & $5 \times 10^{6}$ \\
$\mathrm{H}_{2} \mathrm{O}_{2}$ & $2 \times 10^{10 b}$ \\
$\mathrm{HNO}_{3}$ & $2.55 \times 10^{10} b$ \\
$\mathrm{HCHO}^{10}$ & $2 \times 10^{8} b$ \\
$\mathrm{HNO}_{2}$ & $2 \times 10^{8}$ \\
$\mathrm{HCOOH}^{8}$ & $2 \times 10^{11}$ \\
$\mathrm{CH}_{3} \mathrm{O}_{2}$ & $3 \times 10^{8}$ \\
$\mathrm{CH}_{3} \mathrm{OOH}$ & $2.55 \times 10^{8} b$ \\
$\mathrm{NO}_{2}$ & $1.75 \times 10^{10 b}$ \\
$\mathrm{~N}_{2} \mathrm{O}_{5}$ & $5 \times 10^{6}$ \\
$\mathrm{O}_{3}$ & $5 \times 10^{11 b}$ \\
$\mathrm{CH}_{3} \mathrm{OH}$ & $1.275 \times 10^{11 b}$ \\
$\mathrm{HO}_{2} \mathrm{NO}$ & $3 \times 10^{7}$ \\
$\mathrm{NO}^{7}$ & $6 \times 10^{9}$ \\
\end{tabular}

${ }^{a}$ Leuenberger et al., 1988

${ }^{b}$ Herrmann et al., 1999; Herrmann et al., 2000
Table A3. Initial concentrations of time-dependent liquid phase species.

\begin{tabular}{|c|c|}
\hline Variable & Initial concentration/moles $\mathrm{L}^{-1}$ \\
\hline $\mathrm{H}^{+}$ & $3.16 \times 10^{-5}$ \\
\hline $\mathrm{OH}^{-}$ & $4 \times 10^{-12}$ \\
\hline $\mathrm{O}_{2}^{-}$ & $1 \times 10^{-10}$ \\
\hline $\mathrm{NO}_{3}^{-}$ & $1 \times 10^{-10}$ \\
\hline $\mathrm{NO}_{2}^{-}$ & $1 \times 10^{-11}$ \\
\hline $\mathrm{O}_{2} \mathrm{NO}_{2}^{-}$ & $1 \times 10^{-10}$ \\
\hline $\mathrm{H}_{2} \mathrm{CO}_{3}^{2}$ & $5 \times 10^{-10}$ \\
\hline $\mathrm{CO}_{3}^{2-}$ & $1 \times 10^{-22}$ \\
\hline $\mathrm{CO}_{3}^{-}$ & $1 \times 10^{-18}$ \\
\hline $\mathrm{CH}_{2} \mathrm{OHOH}$ & $4 \times 10^{-5}$ \\
\hline $\mathrm{HCOO}^{-}$ & $3 \times 10^{-6}$ \\
\hline $\mathrm{HCO}_{3}^{-}$ & $1 \times 10^{-14}$ \\
\hline $\mathrm{HOCl}$ & $1 \times 10^{-10}$ \\
\hline $\mathrm{Cl}_{2}$ & $6 \times 10^{-18}$ \\
\hline $\mathrm{Cl}_{2}^{-}$ & $1 \times 10^{-13}$ \\
\hline $\mathrm{Cl}^{2}$ & $1 \times 10^{-17}$ \\
\hline $\mathrm{Cl}^{-}$ & $1 \times 10^{-4}$ \\
\hline $\mathrm{HCl}$ & $2 \times 10^{-14}$ \\
\hline $\mathrm{ClOH}^{-}$ & $1 \times 10^{-17}$ \\
\hline PH (phenol) & $8.2 \times 10^{-8} a$ \\
\hline $\mathrm{NO}_{3}$ & $3.5 \times 10^{-13}$ \\
\hline BENZ (benzene) & $6.1 \times 10^{-9} a$ \\
\hline $\mathrm{OH}$ & $5 \times 10^{-15}$ \\
\hline $\mathrm{HO}_{2}$ & $1 \times 10^{-9}$ \\
\hline $\mathrm{H}_{2} \mathrm{O}_{2}$ & $8 \times 10^{-5}$ \\
\hline $\mathrm{HNO}_{3}$ & $2.1 \times 10^{-4}$ \\
\hline $\mathrm{HCHO}$ & $2 \times 10^{-8}$ \\
\hline $\mathrm{HNO}_{2}$ & $4 \times 10^{-10}$ \\
\hline $\mathrm{HCOOH}$ & $5 \times 10^{-5}$ \\
\hline $\mathrm{CH}_{3} \mathrm{O}_{2}$ & $7 \times 10^{-12}$ \\
\hline $\mathrm{CH}_{3} \mathrm{OOH}$ & $1 \times 10^{-10}$ \\
\hline $\mathrm{NO}_{2}$ & $8 \times 10^{-12}$ \\
\hline $\mathrm{N}_{2} \mathrm{O}_{5}$ & $2.75 \times 10^{-13}$ \\
\hline $\mathrm{O}_{3}$ & $2 \times 10^{-10}$ \\
\hline $\mathrm{CH}_{3} \mathrm{OH}$ & $1 \times 10^{-6}$ \\
\hline $\mathrm{CO}_{2}$ & $1.1 \times 10^{-5}$ \\
\hline $\mathrm{HO}_{2} \mathrm{NO}_{2}$ & $1 \times 10^{-7}$ \\
\hline NO & $5 \times 10^{-13}$ \\
\hline
\end{tabular}

${ }^{a}$ (Leuenberger et al., 1988)

Table A4. Emission rates of species introduced into the box model.

\begin{tabular}{ll}
\hline Species & Emission rate/molecules $\mathrm{cm}^{-3} \mathrm{~s}^{-1}$ \\
\hline NO & $2 \times 10^{6}$ \\
PH (phenol) & $7.6 \times 10^{2}$ \\
BENZ (benzene) & $5.1 \times 10^{4}$ \\
\hline
\end{tabular}

Table A5. Dry deposition velocities of species removed from the box model.

\begin{tabular}{ll}
\hline Species & Deposition rates/s \\
\hline $\mathrm{H}_{2} \mathrm{O}_{2}$ & $5 \times 10^{-3} / 1000$ \\
$\mathrm{HNO}_{3}$ & $2 \times 10^{-2} / 1000$ \\
$\mathrm{HNO}_{2}$ & $5 \times 10^{-3} / 1000$ \\
$\mathrm{O}_{3}$ & $\left(2 \times 10^{-3} / 1000\right)+1.089918 \times 10^{-3} \times J \mathrm{NO}_{2}$ \\
$\mathrm{NO}_{2}$ & $2.7248 \times 10^{-4} \times J \mathrm{NO}_{2}$ \\
\hline
\end{tabular}


Table A6. Reactions included in the "clean" chemistry of the gas phase and the corresponding rate coefficient expressions. ([M] is calculated for $1 \mathrm{~atm}$ pressure and model temperature). Data from the IUPAC evaluation unless otherwise stated.

\begin{tabular}{|c|c|}
\hline Reaction & Rate coefficient $/ \mathrm{cm}^{3}$ molecule $^{-1} \mathrm{~s}^{-1}$ \\
\hline $\mathrm{H}_{2} \mathrm{O}_{2}+\mathrm{OH} \rightarrow \mathrm{H}_{2} \mathrm{O}+\mathrm{HO}_{2}$ & $2.9 \times 10^{-12} \exp (-160 / \mathrm{T})$ \\
\hline $\mathrm{NO}+\mathrm{O}_{3} \rightarrow \mathrm{NO}_{2}$ & $1.4 \times 10^{-12} \exp (-1310 / \mathrm{T})$ \\
\hline $\mathrm{O}^{1} \mathrm{D} \rightarrow \mathrm{O}^{3} \mathrm{P}$ & $3.2 \times 10^{-11} \exp (67 / \mathrm{T}) \times[\mathrm{M}]$ \\
\hline $\mathrm{O}_{3}+\mathrm{OH} \rightarrow \mathrm{HO}_{2}$ & $1.7 \times 10^{-12} \exp (-940 / \mathrm{T})$ \\
\hline $\mathrm{O}_{3}+\mathrm{HO}_{2} \rightarrow \mathrm{OH}$ & $2.03 \times 10^{-16} \times(\mathrm{T} / 300)^{4.57} \exp (693 / \mathrm{T})$ \\
\hline $\mathrm{NO}+\mathrm{HO}_{2} \rightarrow \mathrm{NO}_{2}+\mathrm{OH}$ & $3.6 \times 10^{-12} \exp (270 / \mathrm{T})$ \\
\hline $\mathrm{HO}_{2}+\mathrm{HO}_{2} \rightarrow \mathrm{H}_{2} \mathrm{O}_{2}$ & $2.2 \times 10^{-13} \exp (600 / \mathrm{T})$ \\
\hline $\mathrm{HO}_{2}+\mathrm{HO}_{2} \rightarrow \mathrm{H}_{2} \mathrm{O}_{2}$ & $1.9 \times 10^{-33} \times[\mathrm{M}] \exp (980 / \mathrm{T})$ \\
\hline $\mathrm{NO}_{2}+\mathrm{O}_{3} \rightarrow \mathrm{NO}_{3}$ & $1.4 \times 10^{-13} \exp (-2470 / \mathrm{T})$ \\
\hline $\mathrm{NO}+\mathrm{NO}_{3} \rightarrow \mathrm{NO}_{2}+\mathrm{NO}_{2}$ & $1.8 \times 10^{-11} \exp (110 / \mathrm{T})$ \\
\hline $\mathrm{OH}+\mathrm{HO}_{2} \rightarrow \mathrm{H}_{2} \mathrm{O}+\mathrm{O}_{2}$ & $4.8 \times 10^{-11} \exp (250 / \mathrm{T})$ \\
\hline $\mathrm{OH}+\mathrm{OH} \rightarrow \mathrm{H}_{2} \mathrm{O}+\mathrm{O}^{3} \mathrm{P}$ & $6.2 \times 10^{-14} \times(\mathrm{T} / 298)^{2.6} \exp (945 / \mathrm{T})$ \\
\hline $\mathrm{O}^{3} \mathrm{P}+\mathrm{O}_{2} \rightarrow \mathrm{O}_{3}$ & $5.6 \times 10^{-34} \times(\mathrm{T} / 300)^{-2.8} \times[\mathrm{M}]$ \\
\hline \multirow[t]{4}{*}{$\mathrm{OH}+\mathrm{HNO}_{3} \rightarrow \mathrm{H}_{2} \mathrm{O}+\mathrm{NO}_{3}$} & $\begin{array}{l}\text { REUS1+REUS2 } \\
\end{array}$ \\
\hline & REUS $2=($ REUS $3 \times[\mathrm{M}]) /(1+($ REUS $3 \times[\mathrm{M}]) /$ REUS 4$)$ \\
\hline & REUS $3=1.9 \times 10^{-33} \exp (725 / \mathrm{T})$ \\
\hline & REUS4=4.1 $\times 10^{-16} \exp (1440 / \mathrm{T})$ \\
\hline $\mathrm{CO}+\mathrm{OH} \rightarrow \mathrm{H}$ & $1.3 \times 10^{-13} \times(1+(0.6 \times 300 / \mathrm{T}))$ \\
\hline $\mathrm{O}^{3} \mathrm{P}+\mathrm{NO}_{2} \rightarrow \mathrm{NO}$ & $5.5 \times 10^{-12} \exp (188 / \mathrm{T})$ \\
\hline $\mathrm{OH}+\mathrm{HO}_{2} \mathrm{NO}_{2} \rightarrow \mathrm{NO}_{2}{ }^{a}$ & $1.3 \times 10^{-12} \exp (380 / \mathrm{T})$ \\
\hline $\mathrm{O}^{1} \mathrm{D}+\mathrm{N}_{2} \mathrm{O} \rightarrow \mathrm{NO}+\mathrm{NO}$ & $7.2 \times 10^{-11}$ \\
\hline $\mathrm{O}^{1} \mathrm{D}+\mathrm{H}_{2} \mathrm{O} \rightarrow \mathrm{OH}+\mathrm{OH}$ & $2.2 \times 10^{-10}$ \\
\hline $\mathrm{OH}+\mathrm{NO}_{3} \rightarrow \mathrm{HO}_{2}+\mathrm{NO}_{2}$ & $2 \times 10^{-11}$ \\
\hline $\mathrm{OH}+\mathrm{HNO}_{2} \rightarrow \mathrm{H}_{2} \mathrm{O}+\mathrm{NO}_{2}$ & $2.5 \times 10^{-12} \exp (260 / \mathrm{T})$ \\
\hline $\mathrm{N}_{2} \mathrm{O}_{5} \rightarrow \mathrm{HNO}_{3}+\mathrm{HNO}_{3}$ & $1 \times 10^{-6}$ \\
\hline
\end{tabular}

${ }^{a}$ Saunders et al., 1997

Table A7. Termolecular reactions included in the "clean" chemistry of the gas phase and the data used to calculate the corresponding rate coefficient expressions ${ }^{a}$. Data from the IUPAC evaluation unless otherwise stated.

\begin{tabular}{llll}
\hline Reaction & $\boldsymbol{k}_{\mathbf{0}}$ & $\boldsymbol{k}_{\infty}$ & $\boldsymbol{F}_{\boldsymbol{c}}$ \\
\hline $\mathrm{OH}+\mathrm{NO}_{2} \rightarrow \mathrm{HNO}_{3}$ & $2.6 \times 10^{-30} \times(\mathrm{T} / 300)^{-2.9} \times[\mathrm{M}]$ & $7.5 \times 10^{-11}(\mathrm{~T} / 300)^{-0.6}$ & $\exp (-\mathrm{T} / 340)$ \\
$\mathrm{OH}+\mathrm{OH} \rightarrow \mathrm{H}_{2} \mathrm{O}_{2}$ & $6.9 \times 10^{-31} \times(\mathrm{T} / 300)^{-0.8} \times[\mathrm{M}]$ & $2.6 \times 10^{-11}$ & 0.5 \\
$\mathrm{NO}_{2}+\mathrm{NO}_{3} \rightarrow \mathrm{N}_{2} \mathrm{O}_{5}$ & $2.8 \times 10^{-30} \times(\mathrm{T} / 300)^{-3.5} \times[\mathrm{M}]$ & $2 \times 10^{-12}(\mathrm{~T} / 300)^{0.2}$ & $2.5 \exp (-1950 / \mathrm{T})$ \\
& & & $+0.9 \exp (-\mathrm{T} / 430)$ \\
$\mathrm{N}_{2} \mathrm{O}_{5} \rightarrow \mathrm{NO}_{2}+\mathrm{NO}_{3}$ & $1 \times 10^{-3} \times(\mathrm{T} / 300)^{-3.5}$ & $9.7 \times 10^{14}(\mathrm{~T} / 300)^{0.1}$ & $2.5 \exp (-1950 / \mathrm{T})$ \\
$\mathrm{O}^{3} \mathrm{P}+\mathrm{NO}_{2} \rightarrow \mathrm{NO}_{3}$ & $9 \times 10^{-32} \times(\mathrm{T} / 300)^{-2} \times[\mathrm{M}]$ & $2.2 \times 10^{-11}$ & $+0.9 \exp (-\mathrm{T} / 430)$ \\
$\mathrm{H}+\mathrm{O}_{2} \rightarrow \mathrm{HO}_{2}$ & $5.4 \times 10^{-32} \times(\mathrm{T} / 300)^{-1.8} \times[\mathrm{M}]$ & $7.5 \times 10^{-11}$ & $\exp (-\mathrm{T} / 1300)$ \\
$\mathrm{O}^{3} \mathrm{P}+\mathrm{NO} \rightarrow \mathrm{NO}_{2}$ & $1 \times 10^{-31} \times(\mathrm{T} / 300)^{-1.6} \times[\mathrm{M}]$ & $3 \times 10^{-11}(\mathrm{~T} / 300)^{0.3}$ & $\exp (-\mathrm{T} / 498)$ \\
$\mathrm{OH}+\mathrm{NO} \rightarrow \mathrm{HNO}_{2}$ & $7.4 \times 10^{-31} \times(\mathrm{T} / 300)^{-2.4} \times[\mathrm{M}]$ & $3.3 \times 10^{-11}$ & $\exp (-\mathrm{T} / 1850)$ \\
$\mathrm{HO}_{2}+\mathrm{NO}_{2} \rightarrow \mathrm{HO}_{2} \mathrm{NO}_{2}{ }^{b}$ & $1.80 \times 10^{-31} \times(\mathrm{T} / 300)^{-3.2} \times[\mathrm{M}]$ & $4.70 \times 10^{-12}$ & $\exp (-\mathrm{T} / 1420)$ \\
$\mathrm{HO}_{2} \mathrm{NO}_{2} \rightarrow \mathrm{HO}_{2}+\mathrm{NO}_{2}{ }^{b}$ & $4.10 \times 10^{-5} \exp (-10650 / \mathrm{T}) \times[\mathrm{M}]$ & $5.70 \times 10^{15} \exp (-11170 / \mathrm{T})$ & 0.6 \\
\hline
\end{tabular}

${ }^{a}$ Rate coefficients are calculated from the data listed using the Troë formulation as described in the text.

${ }^{b}$ Saunders et al., 1997 
Table A8. Reactions for the gas phase oxidation of methane and the corresponding rate coefficient expressions. Data from the Master Chemical Mechanism.

\begin{tabular}{|c|c|c|c|}
\hline Reaction & \multicolumn{3}{|c|}{ Rate coefficient $/ \mathrm{cm}^{3}$ molecule ${ }^{-1} \mathrm{~s}^{-1 a}$} \\
\hline $\mathrm{OH}+\mathrm{CH}_{4} \rightarrow \mathrm{CH}_{3} \mathrm{O}_{2}$ & \multicolumn{3}{|l|}{$7.44 \times 10^{-18} \times \mathrm{T}^{2} \exp (-1361 / \mathrm{T})$} \\
\hline $\mathrm{CH}_{3} \mathrm{O}_{2}+\mathrm{HO}_{2} \rightarrow \mathrm{CH}_{3} \mathrm{OOH}$ & \multicolumn{3}{|l|}{$4.1 \times 10^{-13} \exp (790 / \mathrm{T})$} \\
\hline $\mathrm{OH}+\mathrm{CH}_{3} \mathrm{NO}_{3} \rightarrow \mathrm{HCHO}+\mathrm{NO}_{2}$ & \multicolumn{3}{|l|}{$1.00 \times 10^{-14} \exp (1060 / \mathrm{T})$} \\
\hline $\mathrm{OH}+\mathrm{CH}_{3} \mathrm{OOH} \rightarrow \mathrm{CH}_{3} \mathrm{O}_{2}$ & \multicolumn{3}{|l|}{$1.90 \times 10^{-12} \exp (190 / \mathrm{T})$} \\
\hline $\mathrm{OH}+\mathrm{CH}_{3} \mathrm{OOH} \rightarrow \mathrm{HCHO}+\mathrm{OH}$ & \multicolumn{3}{|l|}{$1.00 \times 10^{-12} \exp (190 / \mathrm{T})$} \\
\hline $\mathrm{CH}_{3} \mathrm{O}_{2}+\mathrm{NO} \rightarrow \mathrm{CH}_{3} \mathrm{NO}_{3}$ & \multicolumn{3}{|l|}{$3.00 \times 10^{-15} \exp (280 / \mathrm{T})$} \\
\hline $\mathrm{CH}_{3} \mathrm{O}_{2}+\mathrm{NO} \rightarrow \mathrm{CH}_{3} \mathrm{O}+\mathrm{NO}_{2}$ & \multicolumn{3}{|l|}{$3.00 \times 10^{-12} \exp (280 / \mathrm{T})$} \\
\hline $\mathrm{OH}+\mathrm{HCHO} \rightarrow \mathrm{HO}_{2}+\mathrm{CO}$ & \multicolumn{3}{|l|}{$1.20 \times 10^{-14} \times \mathrm{T} \exp (287 / \mathrm{T})$} \\
\hline $\mathrm{CH}_{3} \mathrm{OH}+\mathrm{OH} \rightarrow \mathrm{HO}_{2}+\mathrm{HCHO}$ & \multicolumn{3}{|c|}{$6.01 \times 10^{-18} \times \mathrm{T}^{2} \exp (170 / \mathrm{T})$} \\
\hline $\mathrm{CH}_{3} \mathrm{O}_{2} \rightarrow \mathrm{CH}_{3} \mathrm{O}$ & \multicolumn{3}{|c|}{$0.60 \times 10^{-13} \exp (416 / \mathrm{T}) \times\left[\mathrm{CH}_{3} \mathrm{O}_{2}\right]$} \\
\hline $\mathrm{CH}_{3} \mathrm{O}_{2} \rightarrow \mathrm{HCHO}$ & \multicolumn{3}{|c|}{$0.61 \times 10^{-13} \exp (416 / \mathrm{T}) \times\left[\mathrm{CH}_{3} \mathrm{O}_{2}\right]$} \\
\hline $\mathrm{CH}_{3} \mathrm{O}_{2} \rightarrow \mathrm{CH}_{3} \mathrm{OH}$ & \multicolumn{3}{|c|}{$0.61 \times 10^{-13} \exp (416 / \mathrm{T}) \times\left[\mathrm{CH}_{3} \mathrm{O}_{2}\right]$} \\
\hline $\mathrm{RH}+\mathrm{OH} \rightarrow$ loss & \multicolumn{3}{|c|}{$5 \times 10^{-13}$} \\
\hline $\mathrm{RH}+\mathrm{NO}_{3} \rightarrow$ loss & \multicolumn{3}{|l|}{$1 \times 10^{-15}$} \\
\hline $\mathrm{RO}_{2}+\mathrm{NO} \rightarrow \mathrm{HO}_{2}+\mathrm{NO}_{2}$ & \multicolumn{3}{|l|}{$3.00 \times 10^{-12} \exp (280 / \mathrm{T})$} \\
\hline $\mathrm{CH}_{3} \mathrm{O}_{2}+\mathrm{NO}_{3} \rightarrow \mathrm{CH}_{3} \mathrm{O}+\mathrm{NO}_{2}$ & \multicolumn{3}{|l|}{$1 \times 10^{-12}$} \\
\hline $\mathrm{NO}_{3}+\mathrm{HCHO} \rightarrow \mathrm{HNO}_{3}+\mathrm{CO}+\mathrm{HO}_{2}$ & \multicolumn{3}{|l|}{$5.8 \times 10^{-16}$} \\
\hline $\mathrm{CH}_{3} \mathrm{O} \rightarrow \mathrm{HCHO}+\mathrm{HO}_{2}$ & $7.20 \times 10^{-14} \exp (-1080 / \mathrm{T}) \times[$ & ]$\times 0.2095$ & \\
\hline & $k_{0}$ & $k_{\infty}$ & $F_{c}$ \\
\hline $\mathrm{CH}_{3} \mathrm{O}_{2}+\mathrm{NO}_{2} \rightarrow \mathrm{CH}_{3} \mathrm{O}_{2} \mathrm{NO}_{2}$ & $2.50 \times 10^{-30} \times\left((\mathrm{T} / 300)^{-5.5}\right) \times[\mathrm{M}]$ & $7.50 \times 10^{-12}$ & 0.36 \\
\hline $\mathrm{CH}_{3} \mathrm{O}_{2} \mathrm{NO}_{2} \rightarrow \mathrm{CH}_{3} \mathrm{O}_{2}+\mathrm{NO}_{2}$ & $9.00 \times 10^{-05} \exp (-9694 / \mathrm{T}) \times[\mathrm{M}]$ & $1.10 \times 10^{16} \exp (-10561 / \mathrm{T})$ & 0.36 \\
\hline
\end{tabular}

${ }^{a}$ Rate coefficients for the last and penultimate reactions listed have units of $\mathrm{s}^{-1}$ and $\mathrm{cm}^{6}$ molecule $\mathrm{e}^{-2} \mathrm{~s}^{-1}$, respectively, and are calculated from the listed data using the Troë formulation as described in the text.

Table A9. Gas phase reactions for the mono-aromatic species and corresponding rate coefficient expressions. (BENZ and PH represent benzene and phenol, respectively). Data from the Master Chemical Mechanism.

\begin{tabular}{ll}
\hline Reaction & Rate coefficient $/ \mathrm{cm}^{3}$ molecule $\mathrm{s}^{-1}$ \\
\hline BENZ+OH $\rightarrow$ Ring Opened Species & $3.58 \times 10^{-12} \exp (-280 / \mathrm{T}) \times 0.65 \times 0.5$ \\
BENZ+OH $\rightarrow$ Ring Opened Species $+\mathrm{HO}_{2}$ & $3.58 \times 10^{-12} \exp (-280 / \mathrm{T}) \times 0.65 \times 0.5$ \\
BENZ+OH $\rightarrow \mathrm{PH}+\mathrm{HO}_{2}$ & $3.58 \times 10^{-12} \exp (-280 / \mathrm{T}) \times 0.25$ \\
$\mathrm{BENZ}+\mathrm{OH} \rightarrow \mathrm{Ring}$ Opened Species & $3.58 \times 10^{-12} \exp (-280 / \mathrm{T}) \times 0.10$ \\
$\mathrm{PH}+\mathrm{OH} \rightarrow \mathrm{C}_{6} \mathrm{H}_{5} \mathrm{O}$ & $2.63 \times 10^{-11} \times 0.067$ \\
$\mathrm{PH}+\mathrm{OH} \rightarrow \mathrm{PH}$ loss route & $2.63 \times 10^{-11} \times 0.933$ \\
$\mathrm{PH}+\mathrm{NO}_{3} \rightarrow \mathrm{C}_{6} \mathrm{H}_{5} \mathrm{O}+\mathrm{HNO}$ & \\
$\mathrm{PH}+\mathrm{NO}_{3} \rightarrow \mathrm{PH}_{3}$ loss route & $3.78 \times 10^{-12} \times 0.251$ \\
$\mathrm{C}_{6} \mathrm{H}_{5} \mathrm{O}+\mathrm{NO}_{2} \rightarrow$ NITROPHENOL & $3.78 \times 10^{-12} \times 0.749$ \\
\hline
\end{tabular}

Table A10. Gas phase photochemical reactions and the data used to parameterise the corresponding photochemical rate coefficients.

\begin{tabular}{|c|c|c|c|}
\hline Reaction & A & B & $\mathrm{C}$ \\
\hline $\mathrm{NO}_{2} \rightarrow \mathrm{O}^{3} \mathrm{P}+\mathrm{NO}^{a}$ & $1.03 \times 10^{-2}$ & $9.61800 \times 10^{-1}$ & $8.46710 \times 10^{-1}$ \\
\hline $\mathrm{O}_{3} \rightarrow \mathrm{O}^{1} \mathrm{D}^{a}$ & $5.00 \times 10^{-5}$ & 3.29332 & $8.07820 \times 10^{-1}$ \\
\hline $\mathrm{O}_{3} \rightarrow \mathrm{O}^{3} \mathrm{P}^{a}$ & $5.11 \times 10^{-4}$ & $3.71950 \times 10^{-1}$ & $9.22890 \times 10^{-1}$ \\
\hline $\mathrm{HNO}_{2} \rightarrow \mathrm{OH}+\mathrm{NO}^{a}$ & $2.36 \times 10^{-3}$ & 1.06560 & $8.36440 \times 10^{-1}$ \\
\hline $\mathrm{HNO}_{3} \rightarrow \mathrm{OH}+\mathrm{NO}_{2}{ }^{a}$ & $8.07 \times 10^{-7}$ & 2.30845 & $8.13640 \times 10^{-1}$ \\
\hline $\mathrm{NO}_{3} \rightarrow \mathrm{NO}^{a}$ & $2.59 \times 10^{-2}$ & $2.96180 \times 10^{-1}$ & $9.37480 \times 10^{-1}$ \\
\hline $\mathrm{NO}_{3} \rightarrow \mathrm{NO}_{2}+\mathrm{O}^{3} \mathrm{P}^{a}$ & $2.30 \times 10^{-1}$ & $3.35180 \times 10^{-1}$ & $9.30590 \times 10^{-1}$ \\
\hline $\mathrm{H}_{2} \mathrm{O}_{2} \rightarrow \mathrm{OH}+\mathrm{OH}^{a}$ & $1.18 \times 10^{-5}$ & 1.65050 & $8.16060 \times 10^{-1}$ \\
\hline $\mathrm{HCHO} \rightarrow \mathrm{CO}+\mathrm{HO}_{2}+\mathrm{HO}_{2} b$ & $4.642 \times 10^{-5}$ & 0.762 & -0.353 \\
\hline $\mathrm{HCHO} \rightarrow \mathrm{CO}+\mathrm{H}_{2} \vec{b}$ & $6.853 \times 10^{-5}$ & 0.477 & -0.323 \\
\hline $\mathrm{CH}_{3} \mathrm{OOH} \rightarrow \mathrm{CH}_{3} \mathrm{O}+\mathrm{OH}^{b}$ & $7.649 \times 10^{-6}$ & 0.682 & -0.279 \\
\hline $\mathrm{CH}_{3} \mathrm{NO}_{3} \rightarrow \mathrm{CH}_{3} \mathrm{O}+\mathrm{NO}_{2} b$ & $1.588 \times 10^{-6}$ & 1.154 & -0.318 \\
\hline
\end{tabular}

a Photochemical rate coefficient parameterised using the formula of Poppe et al. (2001), Eq. (3).

$b$ Photochemical rate coefficient parameterised using the formula of Saunders et al. (1997), Eq. (4). 
Table A11. Values of uptake parameters for species undergoing gas-liquid phase transfer. (NP2 and NP4 represent 2- and 4-nitrophenol, respectively). Data from Herrmann et al. $(1999,2000)$ except where otherwise stated.

\begin{tabular}{lllll}
\hline Species & $H / \mathrm{M} \mathrm{atm}^{-1}$ & $\alpha$ & $D_{g} / \mathrm{cm}^{2} \mathrm{~s}^{-1}$ & $\bar{c} / \mathrm{cm} \mathrm{s}^{-1}$ \\
\hline $\mathrm{PH}$ & $\exp ((5850 / \mathrm{T})-11.6)^{a}$ & $0.01^{b}$ & $0.0853^{c}$ & 25908 \\
$\mathrm{NO}_{3}$ & 0.6 & $4 \times 10^{-3}$ & 0.1 & 31901 \\
$\mathrm{BENZ}$ & $\exp ((4000 / \mathrm{T})-15.14)^{d}$ & $1 \times 10^{-3} b$ & $0.0895^{c}$ & 28441 \\
$\mathrm{OH}$ & $25 \exp (5280 \times(1 / \mathrm{T}-1 / 298))$ & 0.05 & 0.153 & 60922 \\
$\mathrm{HO}_{2}$ & $9 \times 10^{3}$ & 0.01 & 0.104 & 43726 \\
$\mathrm{H}_{2} \mathrm{O}_{2}$ & $1 \times 10^{5} \exp (6340 \times(1 / \mathrm{T}-1 / 298))$ & 0.11 & 0.146 & 43078 \\
$\mathrm{HNO}_{3}$ & $2.1 \times 10^{5} \exp (8700 \times(1 / \mathrm{T}-1 / 298))$ & 0.054 & 0.132 & 31647 \\
$\mathrm{HCHO}$ & $3000 \exp (7200 \times(1 / \mathrm{T}-1 / 298))$ & 0.02 & 0.164 & 45860 \\
$\mathrm{HNO}$ & $49 \exp (4880 \times(1 / \mathrm{T}-1 / 298))$ & 0.5 & 0.13 & 36639 \\
$\mathrm{HCOOH}$ & $5 \times 10^{3} \exp (5630 \times(1 / \mathrm{T}-1 / 298))$ & 0.012 & 0.153 & 37035 \\
$\mathrm{CH}_{3} \mathrm{O}_{2}$ & $6 \exp (5640 \times(1 / \mathrm{T}-1 / 298))$ & $3.8 \times 10^{-3}$ & 0.135 & 36639 \\
$\mathrm{CH}_{3} \mathrm{OOH}$ & $6 \exp (5640 \times(1 / \mathrm{T}-1 / 298))$ & $3.8 \times 10^{-3}$ & 0.131 & 36255 \\
$\mathrm{NO}_{2}$ & $1.2 \times 10^{-2} \exp (2500 \times(1 / \mathrm{T}-1 / 298))$ & $1.5 \times 10^{-3}$ & 0.192 & 37035 \\
$\mathrm{~N}_{2} \mathrm{O}_{5}$ & 1.4 & $3.7 \times 10^{-3}$ & 0.11 & 24170 \\
$\mathrm{O}_{3}$ & $1.1 \times 10^{-2} \exp (2300 \times(1 / \mathrm{T}-1 / 298))$ & $5 \times 10^{-2}$ & 0.148 & 36256 \\
$\mathrm{CH}_{3} \mathrm{OH}$ & $2.2 \times 10^{2} \exp (5390 \times(1 / \mathrm{T}-1 / 298))$ & $1.5 \times 10^{-2}$ & 0.116 & 44404 \\
$\mathrm{CO}_{2}$ & $3.1 \times 10^{-2} \exp (2423 \times(1 / \mathrm{T}-1 / 298))$ & $2 \times 10^{-4}$ & 0.155 & 37868 \\
$\mathrm{HO}_{2} \mathrm{NO}{ }_{2}$ & $1 \times 10^{5}$ & 0.1 & 0.13 & 28261 \\
$\mathrm{NO}$ & $1.9 \times 10^{-3}$ & $0.01 e$ & $0.227166^{c}$ & 45860 \\
$\mathrm{NP}$ & $\exp (6270 / \mathrm{T}-16.6)$ & 0.01 & 0.07727 & 21305 \\
$\mathrm{NP}$ & $990 \times \exp (6000 \times(1 / \mathrm{T}-1 / 298)$ & 0.01 & 0.07727 & 21305 \\
\hline
\end{tabular}

${ }^{a}$ Harrison et al., 2002

$b$ estimate

${ }^{c}$ calculated values

${ }^{d}$ obtained from the online database maintained by Sander (1999)

${ }^{e}$ Finlayson-Pitts and Pitts, 2000

Table A14. Liquid phase organic reactions and the corresponding rate coefficient expressions. Data from Herrmann et al. (1999,

Table A12. Liquid phase $\mathrm{OH}$ reactions and the corresponding rate coefficient expressions. Data from Herrmann et al. (1999, 2000).

\begin{tabular}{ll}
\hline Reaction & Rate coefficient/L mol ${ }^{-1} \mathrm{~s}^{-1}$ \\
\hline $\mathrm{O}_{3}+\mathrm{O}_{2}^{-}+\mathrm{H}^{+} \rightarrow 2 \mathrm{O}_{2}+\mathrm{OH}$ & $1.5 \times 10^{9} / \mathrm{H}^{+}$ \\
$\mathrm{HO}_{2}+\mathrm{HO}_{2} \rightarrow \mathrm{O}_{2}+\mathrm{H}_{2} \mathrm{O}_{2}$ & $8.3 \times 10^{5} \exp (-2720 \times(1 / \mathrm{T}-1 / 298))$ \\
$\mathrm{HO}_{2}+\mathrm{O}_{2}^{-}+\mathrm{H}^{+} \rightarrow \mathrm{H}_{2} \mathrm{O}_{2}+\mathrm{O}_{2}$ & $9.7 \times 10^{7} \exp (-1060 \times(1 / \mathrm{T}-1 / 298)) / \mathrm{H}^{+}$ \\
$\mathrm{HO}_{2}+\mathrm{OH} \rightarrow \mathrm{H}_{2} \mathrm{O}+\mathrm{O}_{2}$ & $1 \times 10^{10}$ \\
$\mathrm{O}_{2}^{-}+\mathrm{OH} \rightarrow \mathrm{OH}^{-}+\mathrm{O}_{2}$ & $1.1 \times 10^{10} \exp (-2120 \times(1 / \mathrm{T}-1 / 298))$ \\
$\mathrm{H}_{2} \mathrm{O}_{2}+\mathrm{OH} \rightarrow \mathrm{HO}_{2}+\mathrm{H}_{2} \mathrm{O}$ & $3 \times 10^{7} \exp (-1680 \times(1 / \mathrm{T}-1 / 298))$ \\
$\mathrm{CH}_{3} \mathrm{OOH}+\mathrm{OH} \rightarrow \mathrm{CH}_{3} \mathrm{O}_{2}+\mathrm{H}_{2} \mathrm{O}$ & $3 \times 10^{7} \exp (-1680 \times(1 / \mathrm{T}-1 / 298))$ \\
\hline
\end{tabular}

Table A13. Liquid phase nitrogen-species reactions and the corresponding rate coefficient expressions. Data from Herrmann et al. (1999, 2000).

\begin{tabular}{ll}
\hline Reaction & Rate coefficient/L mol ${ }^{-1} \mathrm{~s}^{-1}$ \\
\hline $\mathrm{N}_{2} \mathrm{O}_{5}+\mathrm{H}_{2} \mathrm{O} \rightarrow \mathrm{H}^{+}+\mathrm{H}^{+}+\mathrm{NO}_{3}^{-}+\mathrm{NO}_{3}^{-}$ & $5 \times 10^{9} \exp (-1800 \times(1 / \mathrm{T}-1 / 298))$ \\
$\mathrm{NO}_{3}+\mathrm{OH}^{-} \rightarrow \mathrm{NO}_{3}^{-}+\mathrm{OH}$ & $9.4 \times 10^{7} \exp (-2700 \times(1 / \mathrm{T}-1 / 298))$ \\
$\mathrm{NO}_{3}+\mathrm{H}_{2} \mathrm{O}_{2} \rightarrow \mathrm{NO}_{3}^{-}+\mathrm{H}^{+}+\mathrm{HO}_{2}$ & $4.9 \times 10^{6} \exp (-2000 \times(1 / \mathrm{T}-1 / 298))$ \\
$\mathrm{NO}_{3}+\mathrm{CH}_{3} \mathrm{OOH} \rightarrow \mathrm{NO}_{3}^{-}+\mathrm{H}^{+}+\mathrm{CH}_{3} \mathrm{O}_{2}$ & $4.9 \times 10^{6} \exp (-2000 \times(1 / \mathrm{T}-1 / 298))$ \\
$\mathrm{NO}_{3}+\mathrm{HO}_{2} \rightarrow \mathrm{NO}_{3}^{-}+\mathrm{H}^{+}+\mathrm{O}_{2}$ & $3 \times 10^{9}$ \\
$\mathrm{NO}_{3}+\mathrm{O}_{2}^{-} \rightarrow \mathrm{NO}_{3}^{-}+\mathrm{O}_{2}$ & $3 \times 10^{9}$ \\
$\mathrm{NO}_{2}+\mathrm{OH} \rightarrow \mathrm{NO}_{3}^{-}+\mathrm{H}^{+}$ & $1.2 \times 10^{10}$ \\
$\mathrm{NO}_{2}+\mathrm{O}_{2}^{-} \rightarrow \mathrm{NO}_{2}^{-}+\mathrm{O}_{2}$ & $1 \times 10^{8}$ \\
$\mathrm{NO}_{2}+\mathrm{NO}_{2} \rightarrow \mathrm{HNO}_{2}+\mathrm{NO}_{3}^{-}+\mathrm{H}^{+}$ & $1 \times 10^{8} \exp (2900 \times(1 / \mathrm{T}-1 / 298))$ \\
$\mathrm{O}_{2} \mathrm{NO}_{2}^{-} \rightarrow \mathrm{NO}_{2}^{-}+\mathrm{O}_{2}$ & $4.5 \times 10^{-2}$ \\
$\mathrm{NO}_{2}^{-}+\mathrm{OH}_{\rightarrow} \rightarrow \mathrm{NO}_{2}+\mathrm{OH}^{-}$ & $1.1 \times 10^{10}$ \\
$\mathrm{NO}_{2}^{-}+\mathrm{NO}_{3} \rightarrow \mathrm{NO}_{3}^{-}+\mathrm{NO}_{2}$ & $1.4 \times 10^{9}$ \\
$\mathrm{NO}_{2}^{-}+\mathrm{Cl}_{2}^{-} \rightarrow \mathrm{Cl}^{-}+\mathrm{Cl}^{-}+\mathrm{NO}_{2}$ & $6 \times 10^{7}$ \\
$\mathrm{NO}_{2}^{-}+\mathrm{CO}_{3}^{-} \rightarrow \mathrm{CO}_{3}^{2-}+\mathrm{NO}_{2}$ & $6.6 \times 10^{5} \exp (-850 \times(1 / \mathrm{T}-1 / 298))$ \\
$\mathrm{NO}_{2}^{-}+\mathrm{O}_{3} \rightarrow \mathrm{NO}_{3}^{-}+\mathrm{O}_{2}$ & $5 \times 10^{5} \exp (-6900 \times(1 / \mathrm{T}-1 / 298))$ \\
$\mathrm{HNO}_{2}+\mathrm{OH}^{-} \rightarrow \mathrm{NO}_{2}+\mathrm{H}_{2} \mathrm{O}$ & $1 \times 10^{9}$ \\
\hline
\end{tabular}

\begin{tabular}{ll}
\hline Reaction & Rate coefficient/L mol ${ }^{-1} \mathrm{~s}^{-1}$ \\
\hline $\mathrm{CH}_{3} \mathrm{OH}+\mathrm{OH} \rightarrow \mathrm{H}_{2} \mathrm{O}+\mathrm{HO}_{2}+\mathrm{HCHO}$ & $1 \times 10^{9} \exp (-580 \times(1 / \mathrm{T}-1 / 298))$ \\
$\mathrm{CH}_{3} \mathrm{OH}+\mathrm{NO}_{3} \rightarrow \mathrm{NO}_{3}^{-}+\mathrm{H}^{+}+\mathrm{HO}_{2}+\mathrm{HCHO}$ & $5.4 \times 10^{5} \exp (-4300 \times(1 / \mathrm{T}-1 / 298))$ \\
$\mathrm{CH}_{3} \mathrm{OH}+\mathrm{Cl}_{2}^{-} \rightarrow 2 \mathrm{Cl}^{-}+\mathrm{H}^{+}+\mathrm{HO}_{2}+\mathrm{HCHO}$ & $1000 \exp (-5500 \times(1 / \mathrm{T}-1 / 298))$ \\
$\mathrm{CH}_{3} \mathrm{OH}+\mathrm{CO}_{3}^{-} \rightarrow \mathrm{CO}_{3}^{2-}+\mathrm{H}^{+}+\mathrm{HO}_{2}+\mathrm{HCHO}$ & $2.6 \times 10^{3}$ \\
$\mathrm{CH}_{2}(\mathrm{OH})_{2}+\mathrm{OH} \rightarrow \mathrm{H}_{2} \mathrm{O}+\mathrm{HO}_{2}+\mathrm{HCOOH}_{2}$ & $1 \times 10^{9} \exp (-1020 \times(1 / \mathrm{T}-1 / 298))$ \\
$\mathrm{CH}_{2}(\mathrm{OH})_{2}+\mathrm{NO}_{3} \rightarrow \mathrm{NO}_{3}^{-}+\mathrm{H}^{+}+\mathrm{HO}_{2}+\mathrm{HCOOH}$ & $1 \times 10^{6} \exp (-4500 \times(1 / \mathrm{T}-1 / 298))$ \\
$\mathrm{CH}_{2}(\mathrm{OH})_{2}+\mathrm{Cl}_{2}^{-} \rightarrow \mathrm{Cl}^{-}+\mathrm{Cl}^{-}+\mathrm{H}^{+}+\mathrm{HO}_{2}+\mathrm{HCOOH}$ & $3.1 \times 10^{4} \exp (-4400 \times(1 / \mathrm{T}-1 / 298))$ \\
$\mathrm{CH}_{2}(\mathrm{OH})_{2}+\mathrm{CO}_{3}^{-} \rightarrow \mathrm{CO}_{3}^{2-}+\mathrm{H}^{+}+\mathrm{HO}_{2}+\mathrm{HCOOH}$ & $1.3 \times 10^{4}$ \\
$\mathrm{HCOOH}_{+} \mathrm{OH} \rightarrow \mathrm{H}_{2} \mathrm{O}_{+} \mathrm{HO}_{2}+\mathrm{CO}_{2}$ & $1.3 \times 10^{8} \exp (-1000 \times(1 / \mathrm{T}-1 / 298))$ \\
$\mathrm{HCOO}^{-}+\mathrm{OH}_{\rightarrow} \rightarrow \mathrm{OH}^{-}+\mathrm{HO}_{2}+\mathrm{CO}_{2}$ & $4 \times 10^{9} \exp (-1020 \times(1 / \mathrm{T}-1 / 298))$ \\
$\mathrm{HCOOH}_{+} \mathrm{NO}_{3} \rightarrow \mathrm{NO}_{3}^{-}+\mathrm{H}^{+}+\mathrm{HO}_{2}+\mathrm{CO}_{2}$ & $3.8 \times 10^{5} \exp (-3400 \times(1 / \mathrm{T}-1 / 298))$ \\
$\mathrm{HCOO}^{-}+\mathrm{NO}_{3} \rightarrow \mathrm{NO}_{3}^{-}+\mathrm{HO}_{2}+\mathrm{CO}_{2}$ & $5.1 \times 10^{7} \exp (-2200 \times(1 / \mathrm{T}-1 / 298))$ \\
$\mathrm{HCOOH}_{+} \mathrm{Cl}_{2}^{-} \rightarrow 2 \mathrm{Cl}^{-}+\mathrm{H}^{+}+\mathrm{HO}_{2}+\mathrm{CO}_{2}$ & $5500 \exp (-4500 \times(1 / \mathrm{T}-1 / 298))$ \\
$\mathrm{HCOO}^{-}+\mathrm{Cl}_{2}^{-} \rightarrow \mathrm{Cl}^{-}+\mathrm{Cl}^{-}+\mathrm{HO}_{2}+\mathrm{CO}_{2}$ & $1.3 \times 10^{6}$ \\
$\mathrm{HCOO}^{-}+\mathrm{CO}_{3}^{-} \rightarrow \mathrm{CO}_{3}^{2-}+\mathrm{HO}_{2}+\mathrm{CO}_{2}$ & $1.4 \times 10^{5} \exp (-3300 \times(1 / \mathrm{T}-1 / 298))$ \\
$\mathrm{CH}_{3} \mathrm{O}_{2}+\mathrm{CH}_{3} \mathrm{O}_{2} \rightarrow \mathrm{CH}_{3} \mathrm{OH}_{+}+\mathrm{HCHO}_{2}$ & $1.7 \times 10^{8} \exp (-2200 \times(1 / \mathrm{T}-1 / 298))$ \\
\hline
\end{tabular}

Table A15. Liquid phase chlorine-species reactions and their corresponding rate coefficient expressions. Data from Herrmann et al. (1999, 2000).

\begin{tabular}{ll}
\hline Reaction & Rate coefficient/L mol ${ }^{-1} \mathrm{~s}^{-1}$ \\
\hline $\mathrm{NO}_{3}+\mathrm{Cl}^{-} \rightarrow \mathrm{NO}_{3}^{-}+\mathrm{Cl}$ & $1 \times 10^{7} \exp (-4300 \times(1 / \mathrm{T}-1 / 298))$ \\
$\mathrm{Cl}_{2}^{-}+\mathrm{Cl}_{2}^{-} \rightarrow \mathrm{Cl}_{2}+2 \mathrm{Cl}^{-}$ & $8.7 \times 10^{8}$ \\
$\mathrm{Cl}_{2}^{-}+\mathrm{H}_{2} \mathrm{O}_{2} \rightarrow \mathrm{Cl}^{-}+\mathrm{Cl}^{-}+\mathrm{H}^{+}+\mathrm{HO}_{2}$ & $7 \times 10^{5} \exp (-3340 \times(1 / \mathrm{T}-1 / 298))$ \\
$\mathrm{Cl}_{2}^{-}+\mathrm{CH}_{3} \mathrm{OOH} \rightarrow \mathrm{Cl}^{-}+\mathrm{Cl}^{-}+\mathrm{H}^{+}+\mathrm{CH}_{3} \mathrm{O}_{2}$ & $7 \times 10^{5} \exp (-3340 \times(1 / \mathrm{T}-1 / 298))$ \\
$\mathrm{Cl}_{2}^{-}+\mathrm{OH}^{-} \rightarrow \mathrm{Cl}^{-}+\mathrm{Cl}^{-}+\mathrm{OH}$ & $4 \times 10^{6}$ \\
$\mathrm{Cl}_{2}^{-}+\mathrm{HO}_{2} \rightarrow \mathrm{Cl}^{-}+\mathrm{Cl}^{-}+\mathrm{H}^{+}+\mathrm{O}_{2}$ & $1.3 \times 10^{10}$ \\
$\mathrm{Cl}_{2}^{-}+\mathrm{O}_{2}^{-} \rightarrow 2 \mathrm{Cl}^{-}+\mathrm{O}_{2}$ & $6 \times 10^{9}$ \\
$\mathrm{Cl}_{2}+\mathrm{H}_{2} \mathrm{O} \rightarrow \mathrm{H}^{+}+\mathrm{Cl}^{-}+\mathrm{HOCl}$ & $0.40 \exp (-7900 \times(1 / \mathrm{T}-1 / 298))$ \\
\hline
\end{tabular}


Table A16. Liquid phase carbonate reactions and their corresponding rate coefficient expressions. Data from Herrmann et al. (1999, 2000).

\begin{tabular}{ll}
\hline Reaction & Rate coefficient $/ \mathrm{L} \mathrm{mol}^{-1} \mathrm{~s}^{-1}$ \\
\hline $\mathrm{HCO}_{3}^{-}+\mathrm{OH} \rightarrow \mathrm{H}_{2} \mathrm{O}+\mathrm{CO}_{3}^{-}$ & $1.7 \times 10^{7} \mathrm{exp}(-1900 \times(1 / \mathrm{T}-1 / 298))$ \\
$\mathrm{CO}_{3}^{2-}+\mathrm{OH} \rightarrow \mathrm{OH}^{-}+\mathrm{CO}_{3}^{-}$ & $1 \times 10^{9} \mathrm{exp}(-2550 \times(1 / \mathrm{T}-1 / 298))$ \\
$\mathrm{CO}_{3}^{2-}+\mathrm{NO}_{3} \rightarrow \mathrm{NO}_{3}^{-}+\mathrm{CO}_{3}^{-}$ & $1.7 \times 10^{7}$ \\
$\mathrm{CO}_{3}^{2-}+\mathrm{Cl}_{2}^{-} \rightarrow 2 \mathrm{Cl}^{-}+\mathrm{CO}_{3}^{-}$ & $2.7 \times 10^{6}$ \\
$\mathrm{CO}_{3}^{-}+\mathrm{CO}_{3}^{-} \rightarrow 2 \mathrm{O}_{2}^{-}+2 \mathrm{CO}_{2}$ & $2.2 \times 10^{6}$ \\
$\mathrm{CO}_{3}^{-}+\mathrm{H}_{2} \mathrm{O}_{2} \rightarrow \mathrm{HCO}_{3}^{-}+\mathrm{HO}_{2}$ & $4.3 \times 10^{5}$ \\
$\mathrm{CO}_{3}^{-}+\mathrm{CH}_{3} \mathrm{OOH} \rightarrow \mathrm{HCO}_{3}^{-}+\mathrm{CH}_{3} \mathrm{O}_{2}$ & $4.3 \times 10^{5}$ \\
$\mathrm{CO}_{3}^{-}+\mathrm{HO}_{2} \rightarrow \mathrm{HCO}_{3}^{-}+\mathrm{O}_{2}$ & $6.5 \times 10^{8}$ \\
$\mathrm{CO}_{3}^{-}+\mathrm{O}_{2}^{-} \rightarrow \mathrm{CO}_{3}^{2-}+\mathrm{O}_{2}$ & $6.5 \times 10^{8}$ \\
\hline
\end{tabular}

Table A17. Liquid phase equilibria and the corresponding rate coefficient expressions. Data from Herrmann et al. (1999, 2000).

\begin{tabular}{|c|c|c|}
\hline Reaction & Forward rate coefficient $/ \mathrm{L} \mathrm{mol}^{-1} \mathrm{~s}^{-1}$ & Backward rate coefficient $/ \mathrm{L} \mathrm{mol}^{-1} \mathrm{~s}^{-1}$ \\
\hline $\mathrm{H}_{2} \mathrm{O}=\mathrm{H}^{+}+\mathrm{OH}^{-}$ & $2.34 \times 10^{-5} \exp (-6800 \times(1 / \mathrm{T}-1 / 298))$ & $1.3 \times 10^{11}$ \\
\hline $\mathrm{CO}_{2}+\mathrm{H}_{2} \mathrm{O}=\mathrm{H}_{2} \mathrm{CO}_{3}$ & $4.3 \times 10^{-2} \exp (-9250 \times(1 / \mathrm{T}-1 / 298))$ & $5.6 \times 10^{4} \exp (-8500 \times(1 / \mathrm{T}-1 / 298))$ \\
\hline $\mathrm{H}_{2} \mathrm{CO}_{3}=\mathrm{H}^{+}+\mathrm{HCO}_{3}^{-}$ & $1 \times 10^{7}$ & $5 \times 10^{10}$ \\
\hline $\mathrm{HCO}_{3}^{-}=\mathrm{H}^{+}+\mathrm{CO}_{3}^{2-}$ & $2.35 \exp (-1820 \times(1 / \mathrm{T}-1 / 298))$ & $5 \times 10^{10}$ \\
\hline $\mathrm{HO}_{2}=\mathrm{H}^{+}+\mathrm{O}_{2}^{-}$ & $8 \times 10^{5}$ & $5 \times 10^{10}$ \\
\hline $\mathrm{HNO}_{3}=\mathrm{H}^{+}+\mathrm{NO}_{3}^{-}$ & $1.1 \times 10^{12} \exp (1800 \times(1 / \mathrm{T}-1 / 298))$ & $5 \times 10^{10}$ \\
\hline $\mathrm{HNO}_{2}=\mathrm{H}^{+}+\mathrm{NO}_{2}^{-}$ & $2.65 \times 10^{7} \exp (-1760 \times(1 / \mathrm{T}-1 / 298))$ & $5 \times 10^{10}$ \\
\hline $\mathrm{HO}_{2} \mathrm{NO}_{2}=\mathrm{H}^{+}+\mathrm{O}_{2} \mathrm{NO}_{2}^{-}$ & $5 \times 10^{5}$ & $5 \times 10^{10}$ \\
\hline $\mathrm{NO}_{2}+\mathrm{HO}_{2}=\mathrm{HO}_{2} \mathrm{NO}_{2}$ & $1 \times 10^{7}$ & $4.6 \times 10^{-3}$ \\
\hline $\mathrm{HCOOH}=\mathrm{HCOO}^{-}+\mathrm{H}^{+}$ & $8.85 \times 10^{6} \exp (12 \times(1 / \mathrm{T}-1 / 298))$ & $5 \times 10^{10}$ \\
\hline $\mathrm{HCHO}+\mathrm{H}_{2} \mathrm{O}=\mathrm{CH}_{2}(\mathrm{OH})_{2}$ & $0.18 \exp (4030 \times(1 / \mathrm{T}-1 / 298))$ & $5.1 \times 10^{-3}$ \\
\hline $\mathrm{Cl}+\mathrm{Cl}^{-}=\mathrm{Cl}_{2}^{-}$ & $2.7 \times 10^{10}$ & $1.4 \times 10^{5}$ \\
\hline $\mathrm{Cl}^{-}+\mathrm{OH}=\mathrm{ClOH}^{-}$ & $4.3 \times 10^{9}$ & $6.1 \times 10^{9}$ \\
\hline $\mathrm{ClOH}^{-}+\mathrm{H}^{+}=\mathrm{Cl}+\mathrm{H}_{2} \mathrm{O}$ & $2.1 \times 10^{10}$ & $1.3 \times 10^{3}$ \\
\hline $\mathrm{ClOH}^{-}+\mathrm{Cl}^{-}=\mathrm{Cl}_{2}^{-}+\mathrm{OH}^{-}$ & $1 \times 10^{4}$ & $4.5 \times 10^{7}$ \\
\hline $\mathrm{HCl}=\mathrm{H}^{+}+\mathrm{Cl}^{-}$ & $8.6 \times 10^{16} \exp (6890 \times(1 / \mathrm{T}-1 / 298))$ & $5 \times 10^{10}$ \\
\hline
\end{tabular}

Table A18. Liquid phase mono-aromatic reactions and the corresponding rate coefficient expressions (BENZ and $\mathrm{PH}$ represent benzene and phenol, respectively).

\begin{tabular}{ll}
\hline Reaction & Rate coefficient/L mol ${ }^{-1} \mathrm{~s}^{-1}$ \\
\hline $\mathrm{BENZ}+\mathrm{OH} \rightarrow \mathrm{PH}$ & $1.55 \times 10^{8} a$ \\
$\mathrm{BENZ}+\mathrm{OH} \rightarrow$ Other products & $1.55 \times 10^{8} a$ \\
$\mathrm{PH}+\mathrm{OH} \rightarrow \mathrm{PH}$ loss route & $6.6 \times 10^{9} b$ \\
$\mathrm{PH}+\mathrm{NO}_{3} \rightarrow \mathrm{NITROPHENOL}$ & $1.8 \times 10^{9} c$
\end{tabular}

$a$ Pan et al., 1993

${ }^{b}$ UNARO, 2001

${ }^{c}$ Barzaghi and Herrmann, 2002

Table A19. Liquid phase photochemical reactions included in the model, together with the constants used to parameterise the corresponding photochemical rate coefficients.

\begin{tabular}{llll}
\hline Reaction & A & B & C \\
\hline $\mathrm{H}_{2} \mathrm{O}_{2} \rightarrow \mathrm{OH}+\mathrm{OH}$ & $1.359 \times 10^{-5}$ & 1.449 & 1.007 \\
$\mathrm{NO}_{2}^{-} \rightarrow \mathrm{NO}+\mathrm{OH}+\mathrm{OH}^{-}$ & $8.757 \times 10^{-5}$ & 1.343 & $9.156 \times 10^{-1}$ \\
$\mathrm{NO}_{3}^{-} \rightarrow \mathrm{NO}_{2}+\mathrm{OH}+\mathrm{OH}^{-}$ & $1.439 \times 10^{-6}$ & 1.480 & 1.019 \\
\hline
\end{tabular}

${ }^{a}$ Photochemical rate coefficient parameterised using the formula of Poppe et al. (2001). 
Acknowledgements. M. A. J. Harrison was supported by a studentship from the UK Engineering and Physical Sciences Research Council and CASE funding from the Centre for Ecology \& Hydrology. We thank the reviewers of this work for their helpful comments.

Edited by: C. George

\section{References}

Atkinson, R., Aschmann, S. M., and Arey, J.: Reactions of $\mathrm{OH}$ and $\mathrm{NO}_{3}$ radicals with phenol, cresols, and 2- nitrophenol at $296 \mathrm{~K}+/-$ 2 K, Environ. Sci. Technol., 26, 1397-1403, 1992.

Barzaghi, P. and Herrmann, H.: A mechanistic study of the oxidation of phenol by $\mathrm{OH} / \mathrm{NO}_{2} / \mathrm{NO}_{3}$ in aqueous solution, Phys. Chem. Chem. Phys., 4, 3669-3675, 2002.

Barzaghi, P. and Herrmann, H.: Kinetics and mechanisms of reactions of the nitrate radical $\left(\mathrm{NO}_{3}\right)$ with subsituted phenols in aqueous solution, Phys. Chem. Chem. Phys., 6, 5379-5388, 2004.

Calvert, J. G., Atkinson, R., Becker, K. H., Kamens, R. M., Seinfeld, J. H., Wallington, T. J., and Yarwood, G.: The mechanisms of atmospheric oxidation of aromatic hydrocarbons, Oxford University Press, 2002.

Cecinato, A., Di Palo, V., Pomata, D., Tomasi Sciano, M. C., and Possanzini, M.: Measurement of phase-distributed nitrophenols in Rome ambient air, Chemosphere, 59, 679-683, 2005.

FACSIMILE: FACSIMILE for Windows Version 3.0, MCPA Software Ltd., 2001.

Finlayson-Pitts, B. J. and Pitts, J. N.: Chemistry of the upper and lower atmosphere: theory, experiments and applications, Academic Press, 2000.

Fuller, E. D., Ensley, K., and Giddings, J. C.: Diffusion of halogenated hydrocarbons in helium. The effect of structure on collision cross sections, J. Phys. Chem., 73, 3679-3685, 1969.

Gilbert, R. G., Luther, K., and Troe, J.: Theory of Thermal Unimolecular Reactions in the Fall-Off Range, 2. Weak Collision Rate Constants, Ber. Bunsenges. Phys. Chem., 87, 169-177, 1983.

Grosjean, D.: Atmospheric fate of toxic aromatic compounds, Sci. Total Environ., 100, 367-414, 1991.

Harrison, M. A. J., Barra, S., Borghesi, D., Vione, D., Arsene, C., and Iulian Olariu, R.: Nitrated phenols in the atmosphere: a review, Atmos. Environ., 39, 231-248, 2005.

Harrison, M. A. J., Cape, J. N., and Heal, M. R.: Experimentally determined Henry's law coefficient of phenol, 2-methylphenol and 2-nitrophenol in the temperature range 281-302 K, Atmos. Environ., 36, 1843-1851, 2002.

Herrmann, H., Ervens, B., Jacobi, H. W., Wolke, R., Nowacki, P., and Zellner, R.: CAPRAM2.3: A chemical aqueous phase radical mechanism for tropospheric chemistry, J. Atmos. Chem., 36, 231-284, 2000.

Herrmann, H., Ervens, B., Nowacki, P., Wolke, R., and Zellner, R.: A chemical aqueous phase radical mechanism for tropospheric chemistry, Chemosphere, 38, 1223-1232, 1999.

Herrmann, H., Exner, M., Jacobi, H. W., Raabe, G., Reese, A., and Zellner, R.: Laboratory studies of atmospheric aqueous-phase free-radical chemistry: Kinetic and spectroscopic studies of reactions of $\mathrm{NO}_{3}$ and $\mathrm{SO}_{4}^{-}$radicals with aromatic compounds, Faraday Discuss., 100, 129-153, 1995.
Herrmann, H., Jacobi, H. W., Raabe, G., Reese, A., and Zellner, R.: Laser-spectroscopic laboratory studies of atmospheric aqueous phase free radical chemistry, Fres. J. Anal. Chem., 355, 343-344, 1996.

Herterich, R. and Herrmann, R.: Comparing the distribution of nitrated phenols in the atmosphere of 2 German hill sites, Environ. Technol., 11, 961-972, 1990.

Klotz, B., Barnes, I., and Becker, K. H.: New results on the atmospheric photooxidation of simple alkylbenzenes, Chem. Phys., 231, 289-301, 1998.

Knispel, R., Koch, R., Siese, M., and Zetzsch, C.: Adduct formation of $\mathrm{OH}$ radicals with benzene, toluene, and phenol and consecutive reactions of the adducts with $\mathrm{NO}_{\mathrm{x}}$ and $\mathrm{O}_{2}$, Ber. Bunsenges. Phys. Chem., 94, 1375-1379, 1990.

Kwok, E. S. C. and Atkinson, R.: Estimation of hydroxyl radical reaction rate constants for gas-phase organic compounds using a structure-activity relationship - an update, Atmos. Environ., 29, 1685-1695, 1995.

Lay, T. H., Bozzelli, J. W., and Seinfeld, J. H.: Atmospheric photochemical oxidation of benzene: Benzene $+\mathrm{OH}$ and the Benzene-OH adduct (Hydroxyl-2,4-cyclohexadienyl) $+\mathrm{O}_{2}$, J. Phys. Chem., 100, 6543-6554, 1996.

Lelieveld, J. and Crutzen, P. J.: Influences of cloud photochemical processes on tropospheric ozone, Nature, 343, 227-233, 1990.

Leuenberger, C., Czuczwa, J., Tremp, J., and Giger, W.: Nitrated phenols in rain: Atmospheric occurrence of phytotoxic pollutants, Chemosphere, 17, 511-515, 1988.

Leuenberger, C., Ligocki, M. P., and Pankow, J. F.: Trace organic compounds in rain. 4. Identities, concentrations, and scavenging mechanisms for phenols in urban air and rain, Environ. Sci. Technol., 19, 1053-1058, 1985.

Levsen, K., Behnert, S., Prieß, B., Svoboda, M., Winkeler, H. D., and Zietlow, J.: Organic compounds in precipitation, Chemosphere, 21, 1037-1061, 1990.

Lüttke, J., Levsen, K., Acker, K., Wieprecht, W., and Möller, D.: Phenols and nitrated phenols in clouds at Mount Brocken, Int. J. Environ. Anal. Chem., 74, 69-89, 1999.

Lüttke, J., Scheer, V., Levsen, K., Wünsch, G., Cape, J. N., Hargreaves, K. J., Storeton-West, R. L., Acker, K., Wieprecht, W., and Jones, B.: Occurrence and formation of nitrated phenols in and out of cloud, Atmos. Environ., 31, 2637-2648, 1997.

Molina, M. J., Molina, L. T., and Kolb, C. E.: Gas-phase and heterogeneous chemical kinetics of the troposphere and stratosphere, Ann. Rev. Phys. Chem., 47, 327-367, 1996.

NAEI: National Atmospheric Emissions Inventory, National Environmental Technology Centre, Abingdon, UK, www.naei.org.uk, 2002.

Natangelo, M., Mangiapan, S., Bagnati, R., Benfenati, E., and Fanelli, R.: Increased concentrations of nitrophenols in leaves from a damaged forestal site, Chemosphere, 38, 1495-1503, 1999.

Nojima, K., Fukaya, K., Fukui, S., and Kanno, S.: The formation of nitrophenols and nitrobenzene by the photochemical reaction of benzene in the presence of nitrogen monoxide, Chemosphere, 2, 77-82, 1975.

Nojima, K., Kawaguchi, A., Ohya, T., Kanno, S., and Hirobe, M.: Studies on photochemical reaction of air pollutants. 10. Identification of nitrophenols in suspended particulates, Chemical \& Pharmaceutical Bulletin, 31, 1047-1051, 1983. 
Pan, X. M., Schuchmann, M. N., and von Sonntag, C.: Oxidation of Benzene by the OH Radical - A Product and Pulse- Radiolysis Study in Oxygenated Aqueous-Solution, J. Chem. Soc. Perkin Trans. 2, 289-297, 1993.

Poppe, D., Aumont, B., Ervens, B., Geiger, H., Herrmann, H., Roth, E. P., Seidl, W., Stockwell, W. R., Vogel, B., Wagner, S., and Weise, D.: Scenarios for modeling multiphase tropospheric chemistry, J. Atmos. Chem., 40, 77-86, 2001.

Richartz, H., Reischl, A., Trautner, F., and Hutzinger, O.: Nitrated phenols in fog, Atmos. Environ., 24, 3067-3071, 1990.

Rippen, G., Zietz, E., Frank, R., Knacker, T., and Klöpffer, W.: Do airborne nitrophenols contribute to forest decline?, Environ. Technol. Lett., 8, 475-482, 1987.

Sander, R.: Compilation of Henry's Law Constants for Inorganic and Organic Species of Potential Importance in Environmental Chemistry (Version 3), http://www.mpch-mainz.mpg.de/ $\sim_{\text {sander/res/henry.html, } 1999 .}$

Saunders, S. M., Jenkin, M. E., Derwent, R. G., and Pilling, M. J.: World Wide Web site of a Master Chemical Mechanism (MCM) for use in tropospheric chemistry models, Atmos. Environ., 31, 1249-1249, 1997.

Schwartz, S. E.: Mass-transport considerations pertinent to aqueous phase reactions of gases in liquid-water clouds, in: Chemistry of multiphase atmospheric systems, edited by: Jaeschke, W., Springer Verlag, Berlin Heidelberg, 415-471, 1986.
Spencer, J. W.: Fourier series representation of the position of the sun, Search, 2, 172-173, 1971.

Tremp, J., Mattrel, P., Fingler, S., and Giger, W.: Phenols and nitrophenols as tropospheric pollutants - emissions from automobile exhausts and phase-transfer in the atmosphere, Water Air Soil Pollut., 68, 113-123, 1993.

Troe, J.: Theory of Thermal Unimolecular Reactions in the FallOff Range .1. Strong Collision Rate Constants, Ber. Bunsenges. Phys. Chem., 87, 161-169, 1983.

Umschlag, T., Zellner, R., and Herrmann, H.: Laser-based studies of $\mathrm{NO}_{3}$ radical reactions with selected aromatic compounds in aqueous solution, Phys. Chem. Chem. Phys., 4, 2975-2982, 2002.

UNARO: Uptake and nitration of aromatics in the tropospheric atmosphere, Final report, EU Environment Research Program contract No. ENV-4-CT-97-0411, 2001.

Vione, D., Maurino, V., Minero, C., Lucchiari, M., and Pelizzeti, E.: Nitration and hydroxylation of benzene in the presence of nitrite/nitrous acid in aqueous solution, Chemosphere, 56, 10491059, 2004.

Voisin, D., Legrand, M., and Chaumerliac, N.: Scavenging of acidic gases $\left(\mathrm{HCOOH}, \mathrm{CH}_{3} \mathrm{COOH}, \mathrm{HNO}_{3}, \mathrm{HCl}\right.$, and $\left.\mathrm{SO}_{2}\right)$ and ammonia in mixed liquid-solid water clouds at the Puy de Dome mountain (France), J. Geophys. Res., 105, 6817-6835, 2000. 